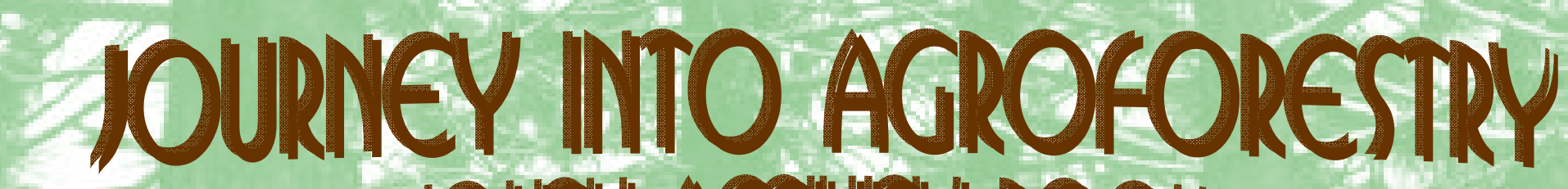
YOUTH ACTNITY BOOK
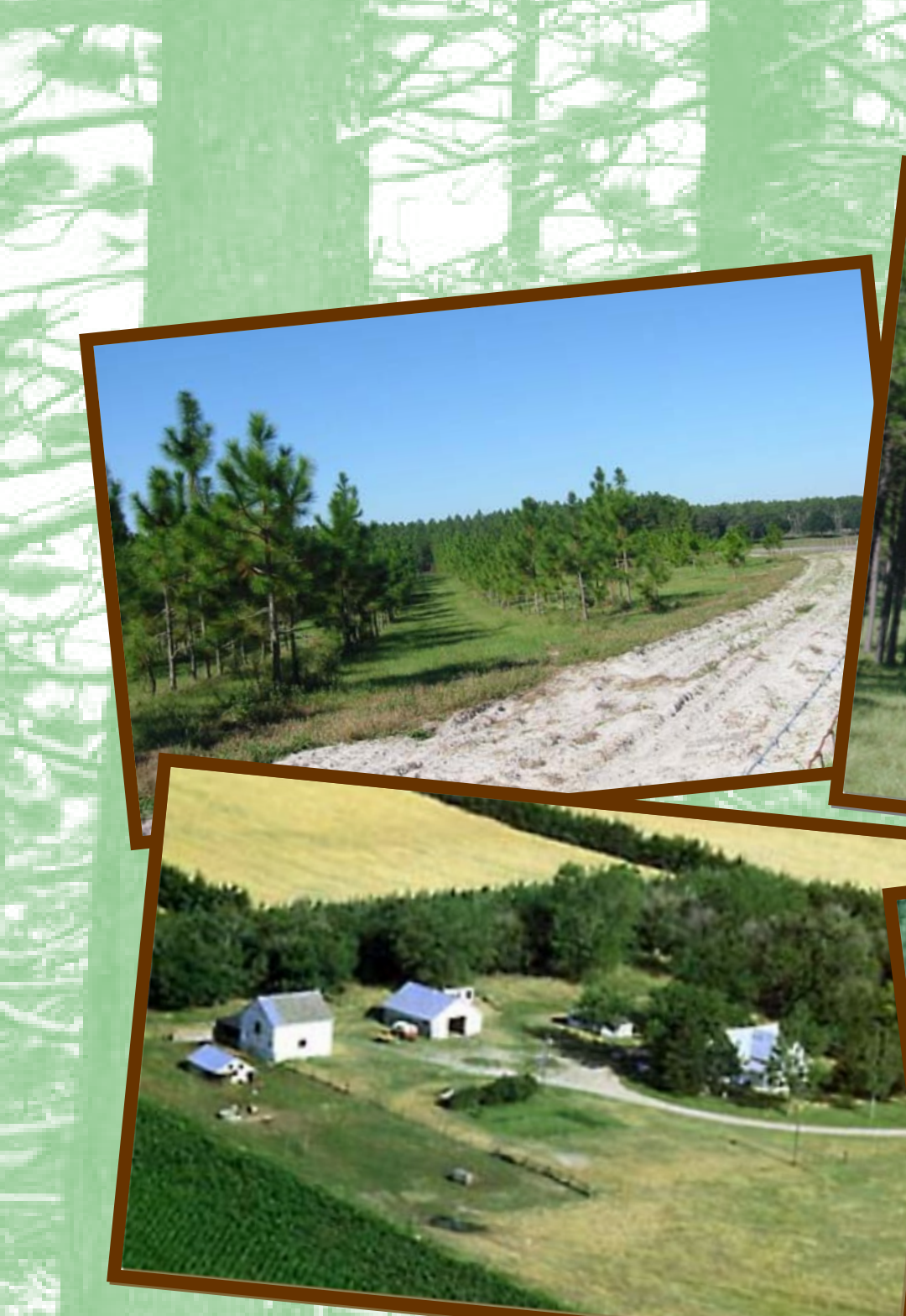

UNIVERSITY OF (3) FLORIDA

IFAS EXTENSION

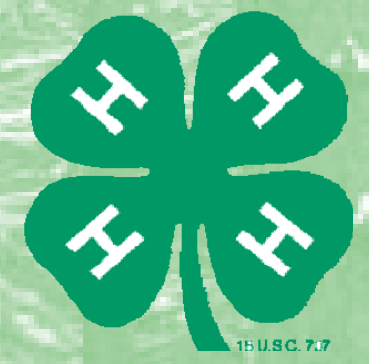




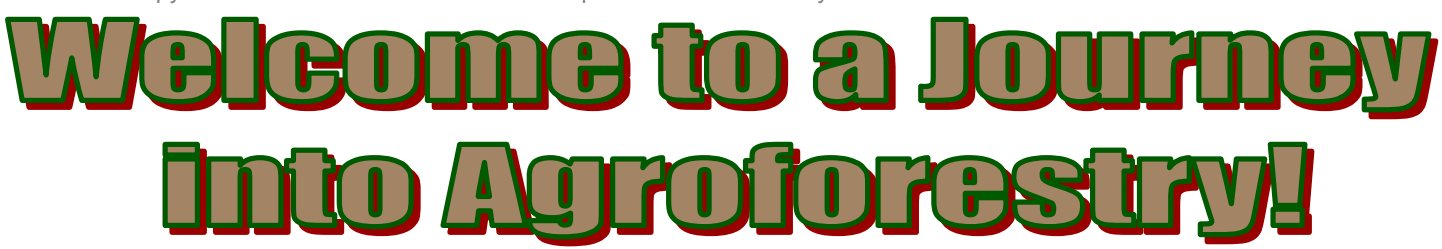

Welcome to your Journey into Agroforestry project book. Do you think you will one day own land? If so, would you like to make the most effective land management decisions? This project in the 4-H Forestry Series takes you on an exploration of some land management decisions and forestry environments within your community and surrounding areas.

The activities in this book ask you to explore your community, ask questions, seek information, and create potential land management plans. Each activity and many of the challenges are designed to help you practice important life skills while learning how to think of alternative solutions to current land management challenges through agroforestry.

\section{What I Want to Do and Learn in this Project:}

\section{The Experiential Learning Model}

The experiential learning model is used in each activity as a means to help you gain the most from the experience.

The five steps in this learning model encourage you to try to do all, part or some of the activity before being told or shown how. The activity is the experience part of the cycle. The questions in the "Let's Talk" section of each activity to encourage you to think about what you have learned from the experience. The reflect and application questions ask you to:

- share what you did;

- process what was most important about the experience;

- generalize the life skill and earth stewardship skill practiced to your own life; and

- apply the life skill or science process skill to a new situation.

To fulfill the experiential learning process you must complete all the steps, including the review questions in "Let's Talk." 


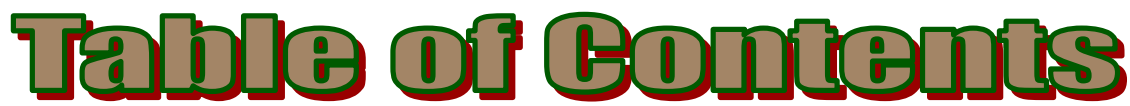

Introduction

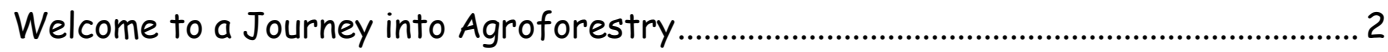

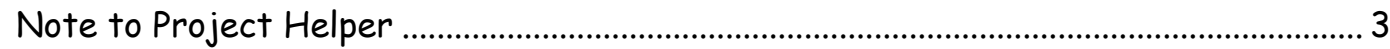

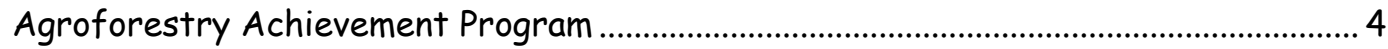

\section{Chapter 1: Introducing Agroforestry}

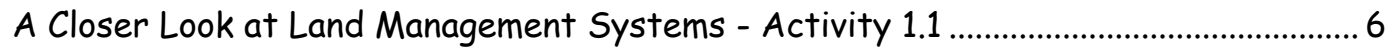

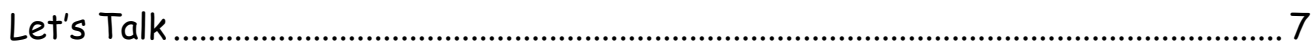

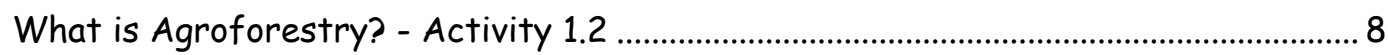

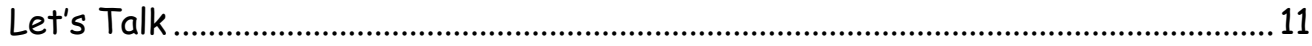

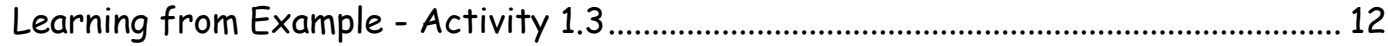

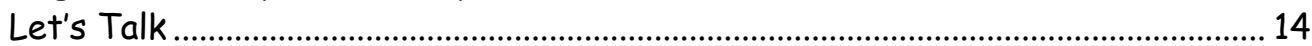

Identifying Agroforestry on your Own - Activity 1.4 …............................................. 15

Practicing Agroforestry in My Community............................................................. 16

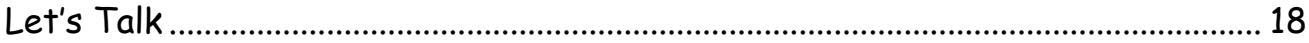

Chapter 2: Is Agroforestry Right for You?

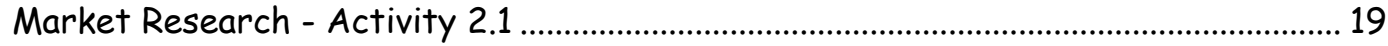

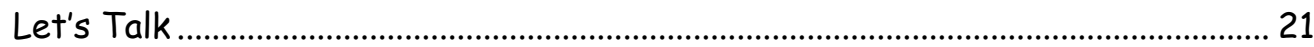

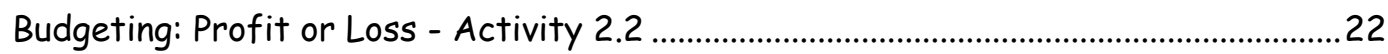

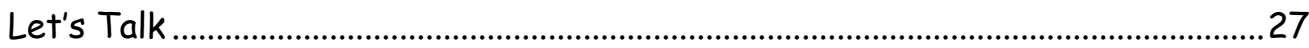

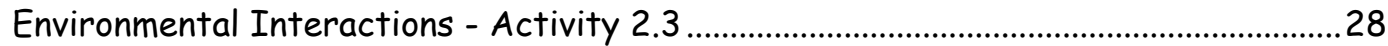

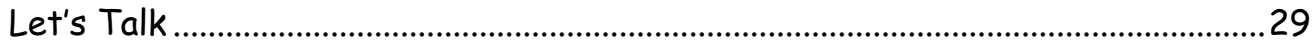

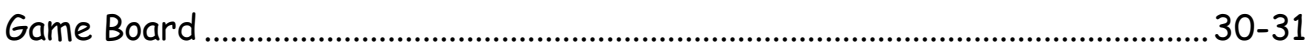

Chapter 3: Agroforestry Action

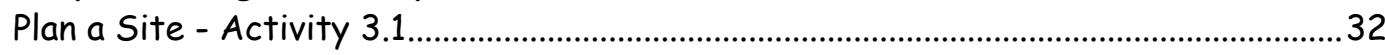

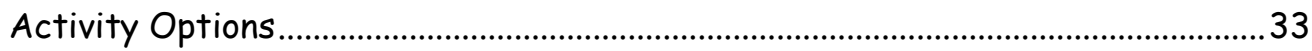

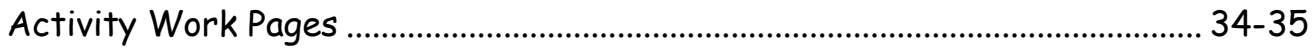

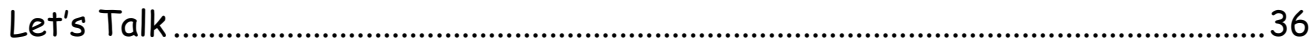

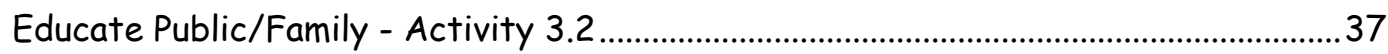

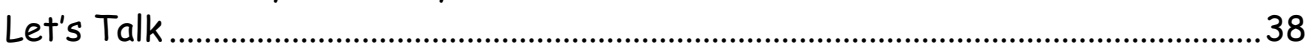

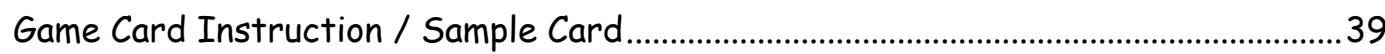

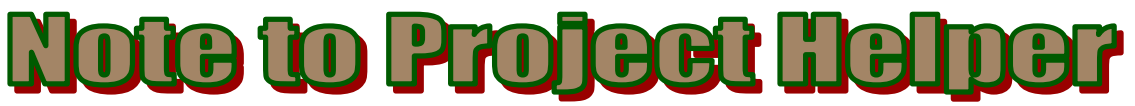

Thank you for volunteering your time to assist one or more young people with this project. Your involvement will make a real difference in the quality of their learning. You play an important role in helping them learn and understand the subject matter or life skills for application to real life issues.

\section{Your Role as Project Helper}

$\checkmark$ Review the material in this book and the Helper's Guide.

$\checkmark$ Give assistance in doing the activities.

$\checkmark$ Try to get the young person to think through why something happened the way it did.

$\checkmark$ Help the child to set goals, discover new ideas and learn new skills.

$\checkmark$ Discuss the review questions after each chapter, listening and encouraging 


\section{Agroforestry Achievement Program Guidelines}

The project book may be used in its entirety as 9 activities. If not, it is recommended that you complete activities 1.1 and 1.2 and then pick and choose from the remaining activities.

$\checkmark$ Do at least 7 activities this year and check them off.

$\checkmark$ Have your agroforestry helper date and initial this log as you complete the activities.

\begin{tabular}{|l|l|l|}
\hline \multicolumn{2}{|c|}{ Project Activities } \\
\hline \multicolumn{1}{|c|}{ Activity Name } & $\begin{array}{c}\text { Date } \\
\text { Completed }\end{array}$ & $\begin{array}{c}\text { Helper's } \\
\text { Initials }\end{array}$ \\
\hline $\begin{array}{l}\text { Agriculture, animal pasture, and } \\
\text { forest plantations }\end{array}$ & & \\
\hline What is Agroforestry & & \\
\hline Learning from example & & \\
\hline Identifying agroforestry on your own & & \\
\hline Market Research & & \\
\hline Why Budgeting? & & \\
\hline Environmental Interactions & & \\
\hline Plan a site & & \\
\hline Educate Public/Family & & \\
\hline
\end{tabular}

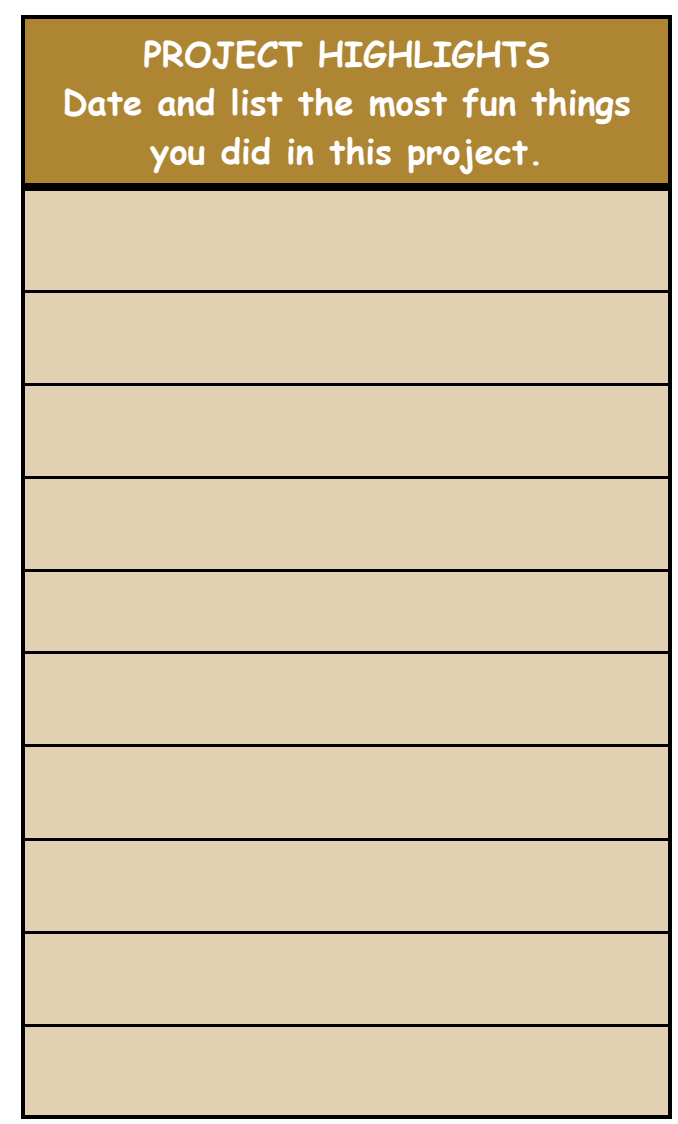

\section{Additional Activities}

Throughout your 4-H project, you may elect to do additional activities such as... an exhibit at the fair, 4-H judging contest or Sill-A-Thon. Record those you have done.

\begin{tabular}{|l|l|l|}
\hline Activity & Date & Helper's Initials \\
\hline & & \\
\hline & &
\end{tabular}




\section{JOURNEY INTO AGROFORESTRY}

I certify that

has successfully completed the requirements of the Journey into Agroforestry Achievement Program.

Agroforestry Helper Date 
The first four activities will help you get to know what agroforestry is and how it relates to you.

Land owners have many options for managing their land. Some make a living by growing crops; others may hold on to it for investment. Farmers have different approaches to managing their land, depending on what they need and what they can produce. Climate, soil conditions and tradition are just some of the factors that may influence how different farmers manage their animals, crops, or trees. It is their choice; there is no set "recipe."

Here are three traditional management systems by which people manage their land to make money and provide products for us all.

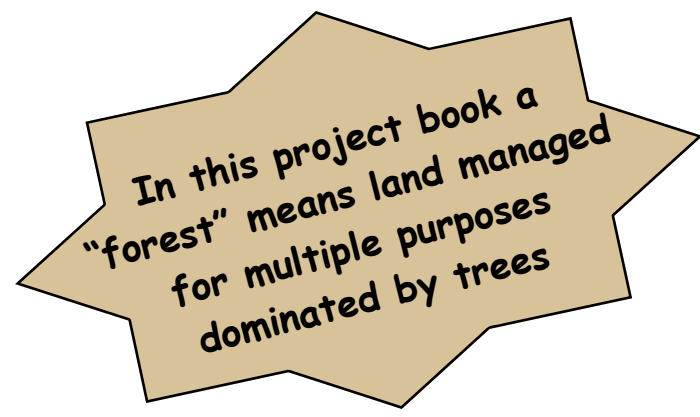

They include:

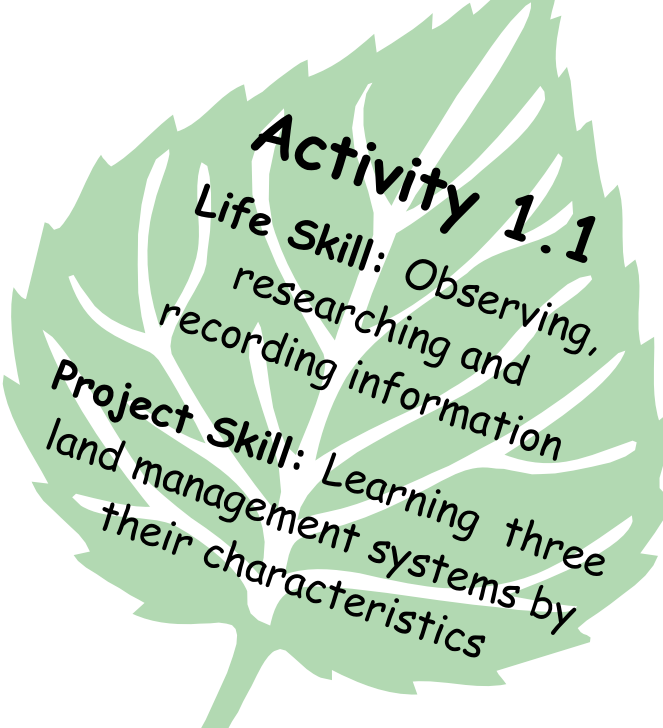

1) Crops managed in an agriculture field

2) Grazing animals managed in a pasture of grass

3) Trees managed in a plantation or forest

\section{A Closer Lools af Land Mlanagement Systems}

Visit each of these agricultural systems, or find pictures on-line and complete this chart.

\begin{tabular}{|l|l|l|l|}
\hline & Agriculture field & Pasture with livestock & Tree plantation or forest \\
\hline 1. What is produced? & & & \\
\hline $\begin{array}{l}\text { 2. How many different prod- } \\
\text { patch of land? }\end{array}$ & & & \\
\hline $\begin{array}{l}\text { 3. How often is the product } \\
\text { harvested? }\end{array}$ & & & \\
\hline $\begin{array}{l}\text { 4. Does it require full sun? } \\
\text { 5. How many layers of } \\
\text { plants are there? Are the } \\
\text { crops all one height? }\end{array}$ & & & \\
\hline $\begin{array}{l}\text { 6. What is the temperature } \\
\text { on the ground and at crop } \\
\text { height? }\end{array}$ & & & \\
\hline $\begin{array}{l}\text { 7. What do you see on the } \\
\text { ground? }\end{array}$ & & & \\
\hline $\begin{array}{l}\text { 8. What are the benefits } \\
\text { other than the products? }\end{array}$ & & & \\
\hline
\end{tabular}




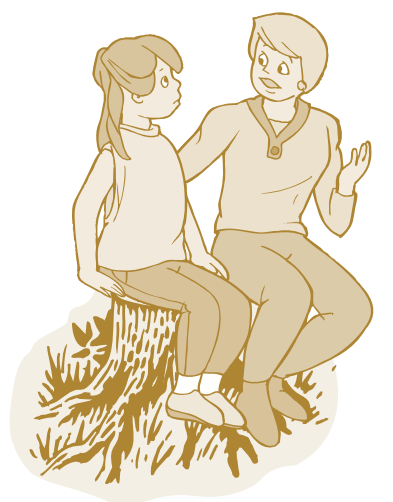

What's important?

What makes these systems similar?

What makes them different?

What characteristics describe each system?

\section{What have you learned?}

Describe other versions of a crop, pasture, or forest systems you have seen.

In which column would you put an orange grove?

A blueberry farm?

How many "products" might be possible in a forest? (example: deer hunting or firewood)
What are the advantages of producing one product on a farm?

\section{Imagine what's next!}

Now imagine trees with crops or trees with animals together on the same land in various patterns - rows, strips, patches, etc. This is agroforestry.

What might be advantages?

What might be disadvantages?

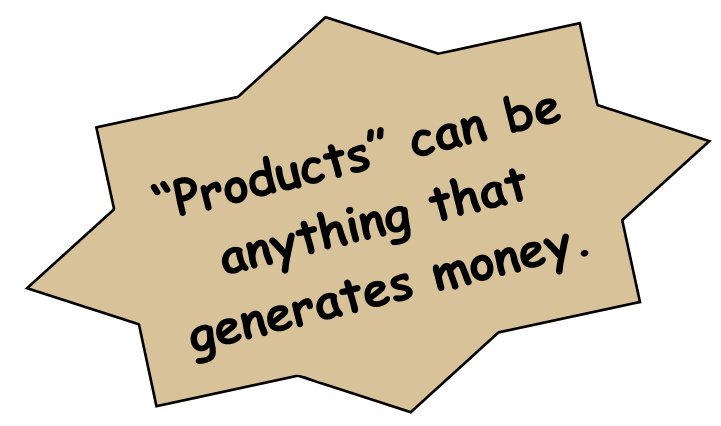




\section{Whats

The tradition of agroforestry dates back thousands of years and has been practiced by people all over the world. It is still practiced today and people benefit in a variety of ways. Agroforestry is a land-management system that takes advantage of the ecological and economic benefits that come from combining trees shrubs with livestock crops. Agroforestry attempts to mimic the natural ecosystem by utilizing the beneficial connections between trees and other parts of the land. There are five different types of agroforestry practiced in the United States that involve these combinations. This section will introduce you to each practice and their benefits.

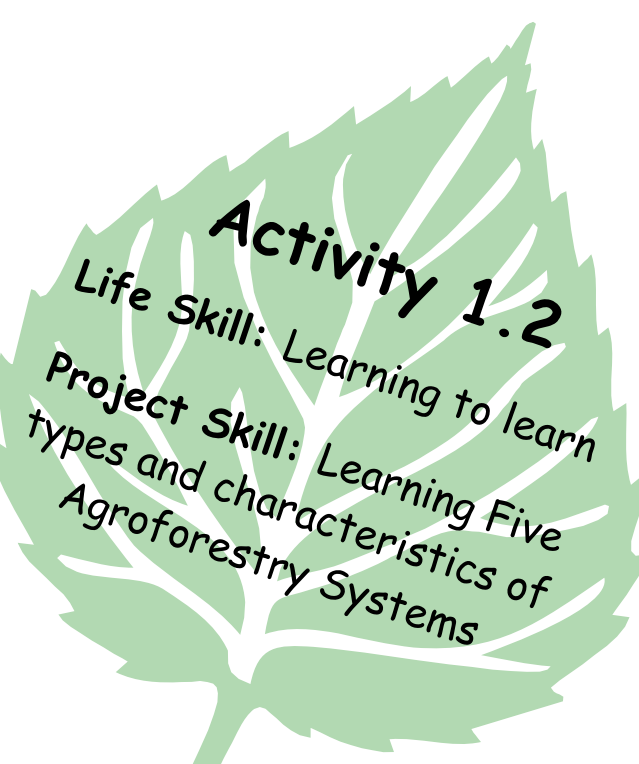

\section{Agroforestry Systems of the USA}

Read the definitions of five agroforestry practices and list the products you see in each picture. Examine the pictures and decide which agroforestry system it represents.

Silvopasture: A system which combines trees with pasture and livestock production.

\section{Land Owner Benefits:}

- more than one source of income: trees and animals vs. only trees or only animals,

- lower fire hazard than thick vegetation that grows underneath tree plantation,

- healthier livestock by protecting them from hot summer sun,

- more wildlife viewing

\section{Environmental Benefits:}

- recycled nutrients from animal waste,

- erosion control,

- enhanced soil fertility

Riparian Forest Buffer: A strip of trees, shrubs, and plants grown beside a river, stream or lake. This area can be managed to harvest products while also protecting water quality.

\section{Land Owner Benefits:}

- harvesting products from land that typically serves solely as environmental protection,

- wildlife viewing

\section{Environmental benefits:}

- protection of water quality,

- erosion control, wildlife habitat and

- travel corridors

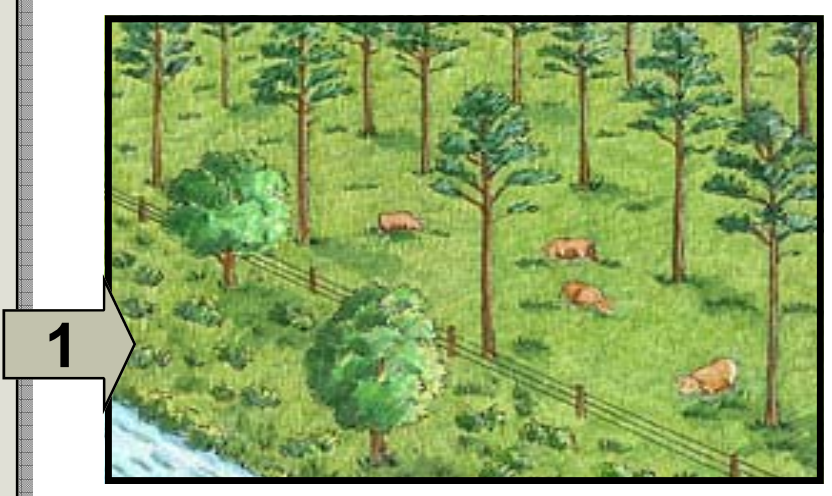

What products do you see?

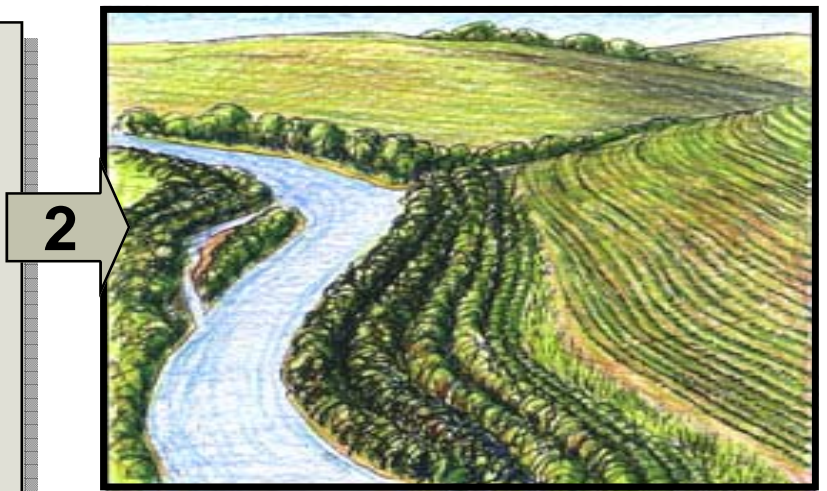

What products do you see? 


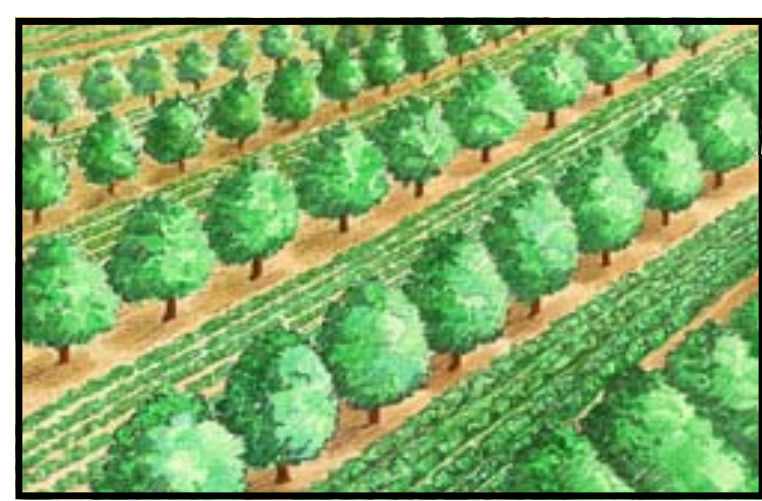

What products do you see?
Land Owner Benefits. ing the year

\section{Environmental benefits.}

- reduces witer runoff and

- provides mind erosion,

crops, organic diverse habitat than single
- cycles nutrients from differned to soil,

Forest Farming: Growing crops under must be the closed cano
shade-tolerant!

Land Owner Benefits: - additional sources of inal plants for - personal use. Environmental benefits: - providing for: - maintains wildife habitat

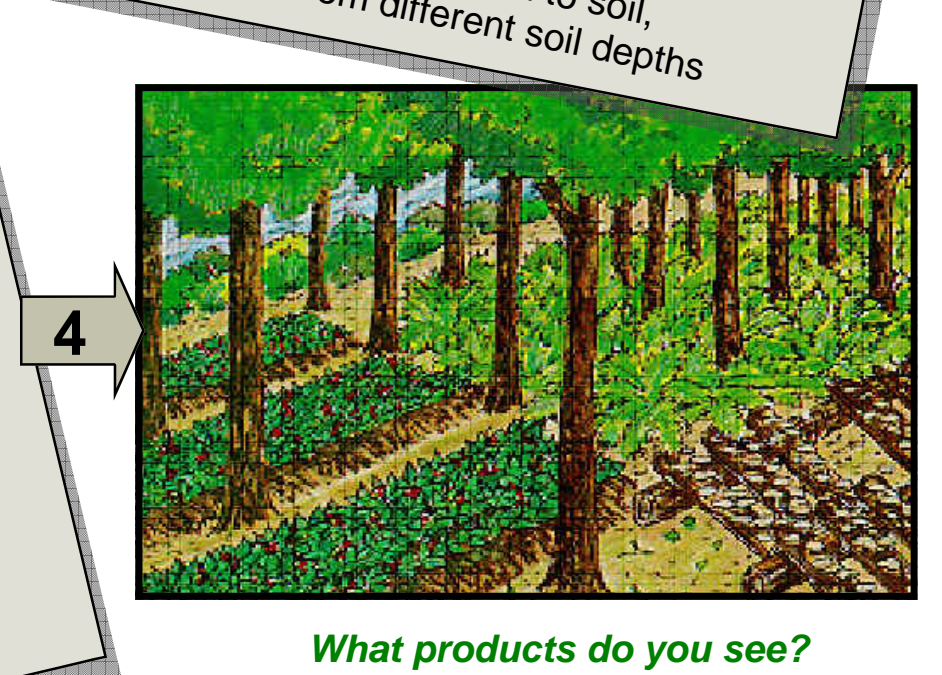

What products do you see?

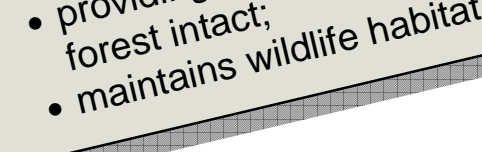

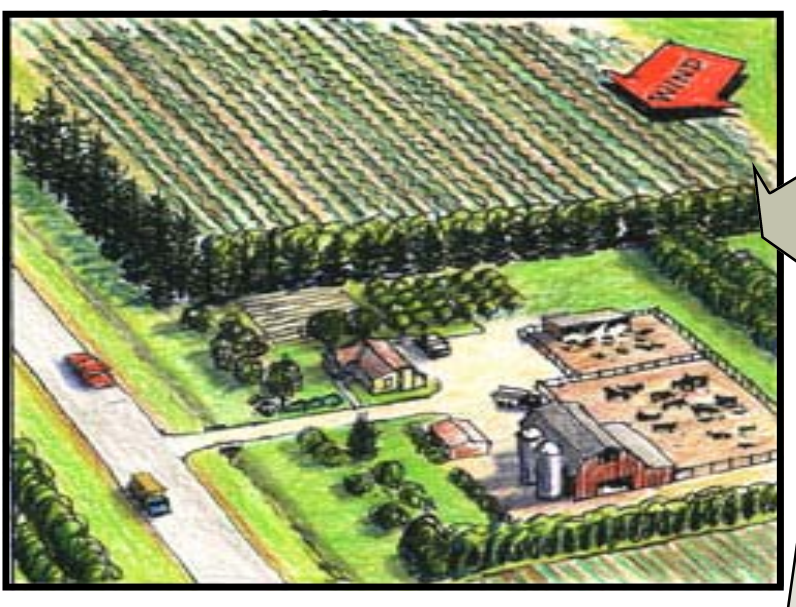

What products do you see? 


\section{Read each scenario, and decide which agroforestry system it represents. (Use the matching number from the previous page.)}

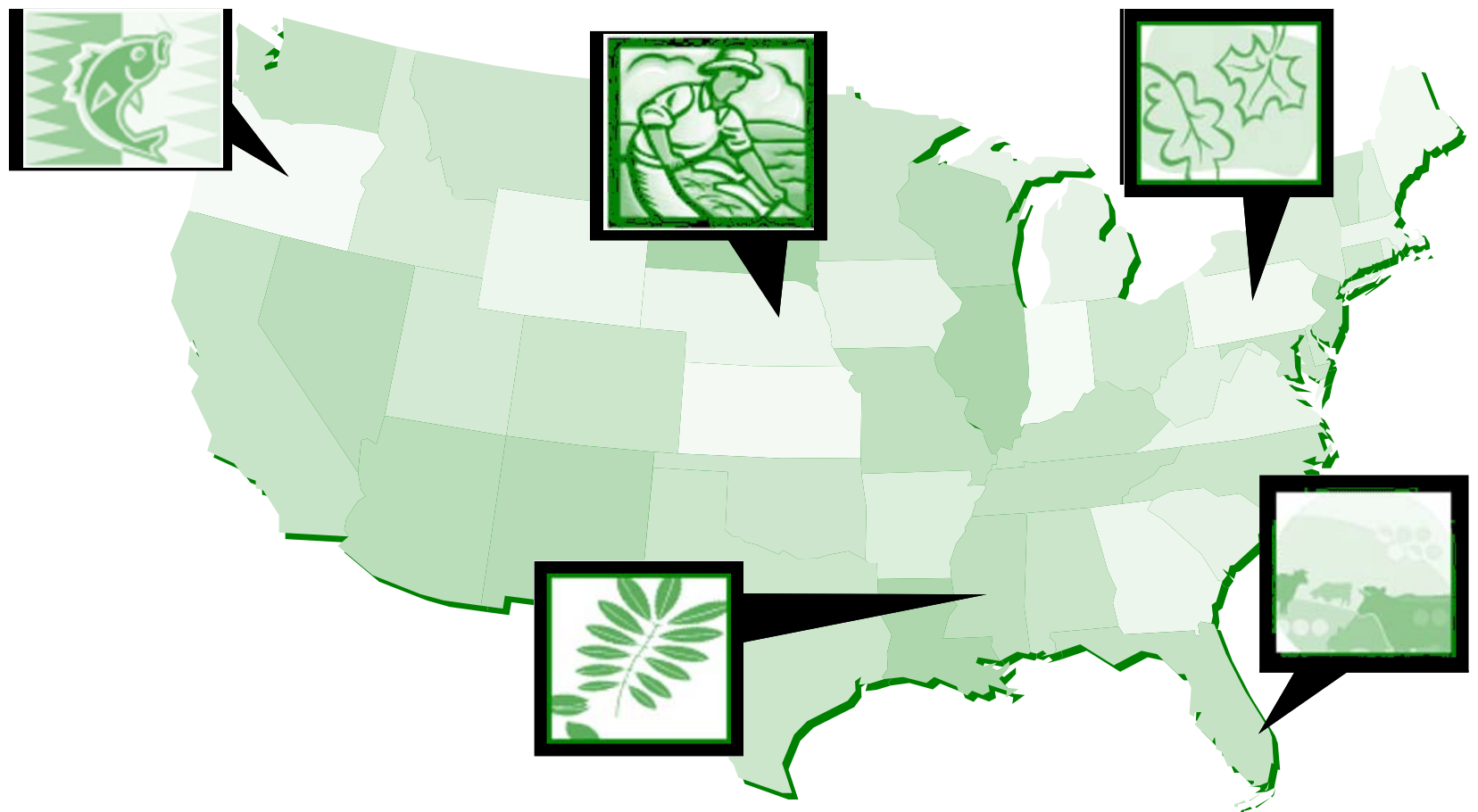

\section{Scenario 1:}

Francisco Mejia grows sunflowers and grazes cows in Nebraska. He wants to increase his yield of sunflowers and protect his cattle from the harsh winter conditions. He decides to plant nut producing trees in a system.

\section{Scenario 3:}

Brian Goldman owns 50 acres of grass pasture and a herd of cattle in Florida. Along one side of the pasture grows a small patch of forest. The cattle often crowd under the forest when it is hot during the day. In order to add income from lumber and relieve heat stress from the cattle, Mr. Goldman decides to plant trees in his pasture to create a system.

\section{Scenario 2:}

Emily Polouski has a pecan orchard in Mississippi. She wants to harvest other crops in addition to the pecan nuts each year. She decides to try an system by growing vegetables and herbs in between the rows of pecan trees. Her brother, who owns the other half of the pecan orchard decides to graze horses under the pecans. He established a system.

\section{Scenario 4:}

James McDonell, in Oregon, wants to start a fish farm in the lake on his property where he raises livestock. However, after testing the water quality, nitrates and particulate matter in the lake water are too high for fish to survive. In order to improve the water quality by filtering out fertilizers and animal wastes on his farm, he installs a system.

\section{Scenario 5:}

Katherine Bloom has a natural oak forest in Pennsylvania and wants to create more income in addition to selling hunting permits. She decides to start a grow mushrooms and medicinal plants in the forest. system to 


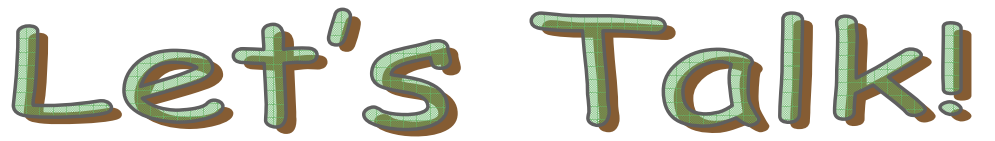

\section{Share with your helper}

$\checkmark$ Describe any agroforestry systems you have seen.

$\checkmark$ Explain the main characteristics of each agroforestry practice.

\section{What's imporkant?}

How would you define agroforestry?

What are two characteristics that all

agroforestry systems share in common?

\section{Imagine what's neklt}

Imagine and describe three ways that these practices might be applied in your area.

How could agroforestry techniques be used in an urban or suburban area?

Why may it be challenging to land owners to try agroforestry?

How can learning new information help you or your community?

What characteristics of an agroforestry system are similar to a natural system?

For each agroforestry system to work the landowner must choose tree or shrubs that will grow well and will produce a marketable product. List the trees or shrubs that might be reasonable to explore for each system in your region.

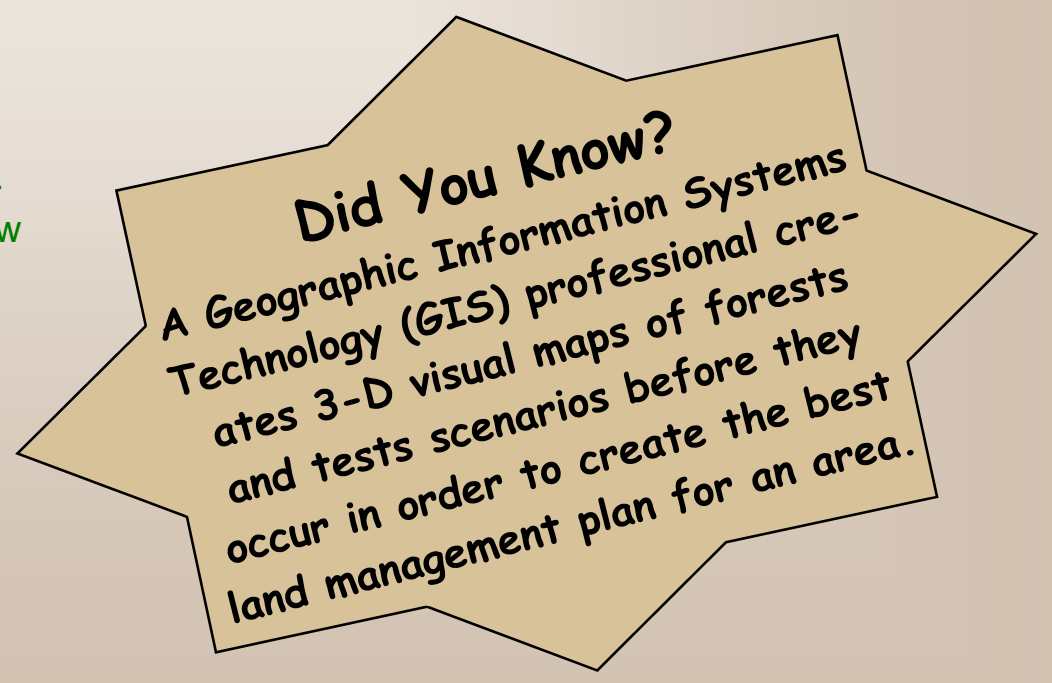




\section{Learinging

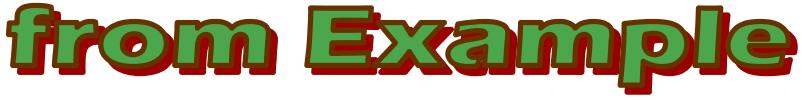

As a newcomer to agroforestry, it is important you learn not only the benefits, but also the costs involved. In the field of agriculture or forestry, people often read "case studies" to better understand a practice. A case study is a written report of a real-life example that is used as a model for others to learn from. To gain practical experience before visiting a real agroforestry site, read this case study and decide what was done correctly and incorrectly.

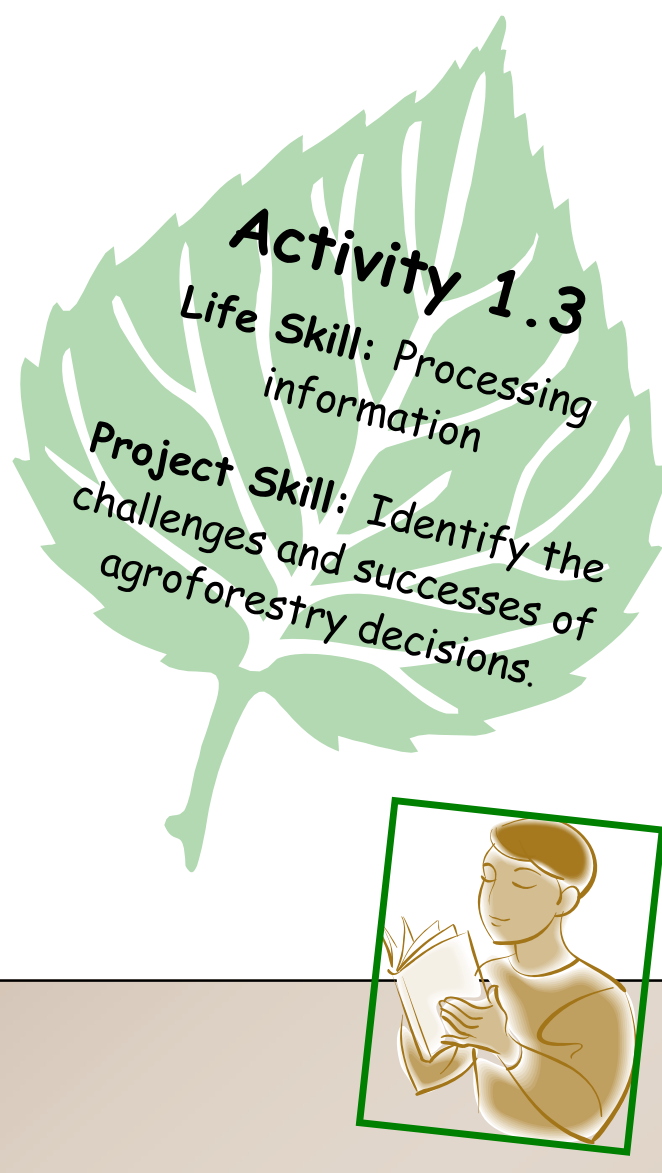

\section{OVERVIEW}

William Gordon manages the Star Ranch in Apopka, Florida. Over the past 13 years, he has established silvopasture systems on 100 acres of land, planting slash pine in various patterns. Previously, these 100 acres were pasture. The silvopasture is surrounded by 1200 acres of land. The land consists of 700 acres of citrus, 300 acres of natural and planted pine, and 200 acres of oak hammock. On the property a lake and wetland contribute to diversity, beauty, and the family's enjoyment of this land.

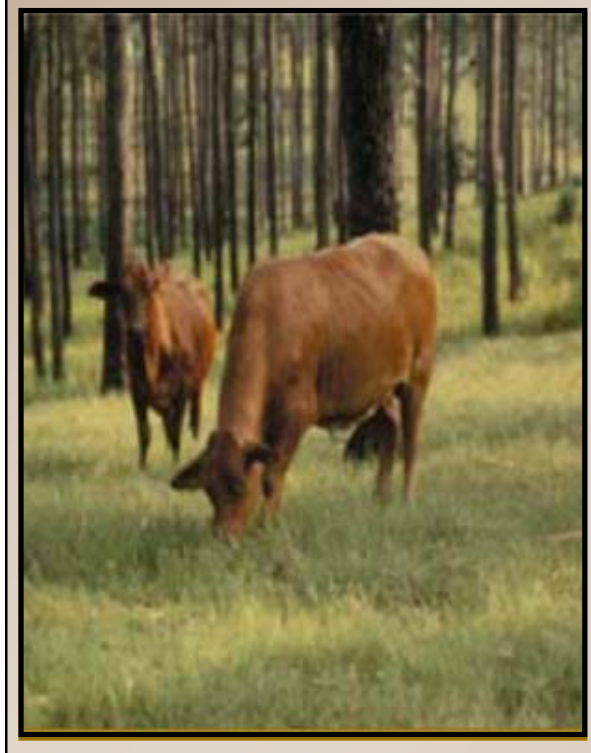

Aside from orange juice, cattle, and timber, Mr. Gordon has made the most of the diversity on his land by selling hunting leases and conducting agrotourism (hosting events and field tours, such as church gatherings). Although this adds to his income, Mr. Gordon has found it difficult to make sure hunters follow the established rules and respect his property as well as his neighbor's property. Safety and liability concerns also cause him to shy away from future hunting lease ventures.

\section{OBJECTIVES}

Mr. Gordon hopes that production of timber through the silvopasture and leasing the land for cattle grazing will earn more money than the previous management of leasing pasture land alone. Mr. Gordon's land is near several Orlando developments. The pressure is greater every year to sell the farm land to developers. Although Mr. Gordon owns and manages the land and tree stands, the cattle that graze these silvopastoral systems are owned by an employee who leases the grazing rights. Because of this, Mr. Gordon has to make sure that the lessee understands all the management decisions that Mr. Gordon makes. 


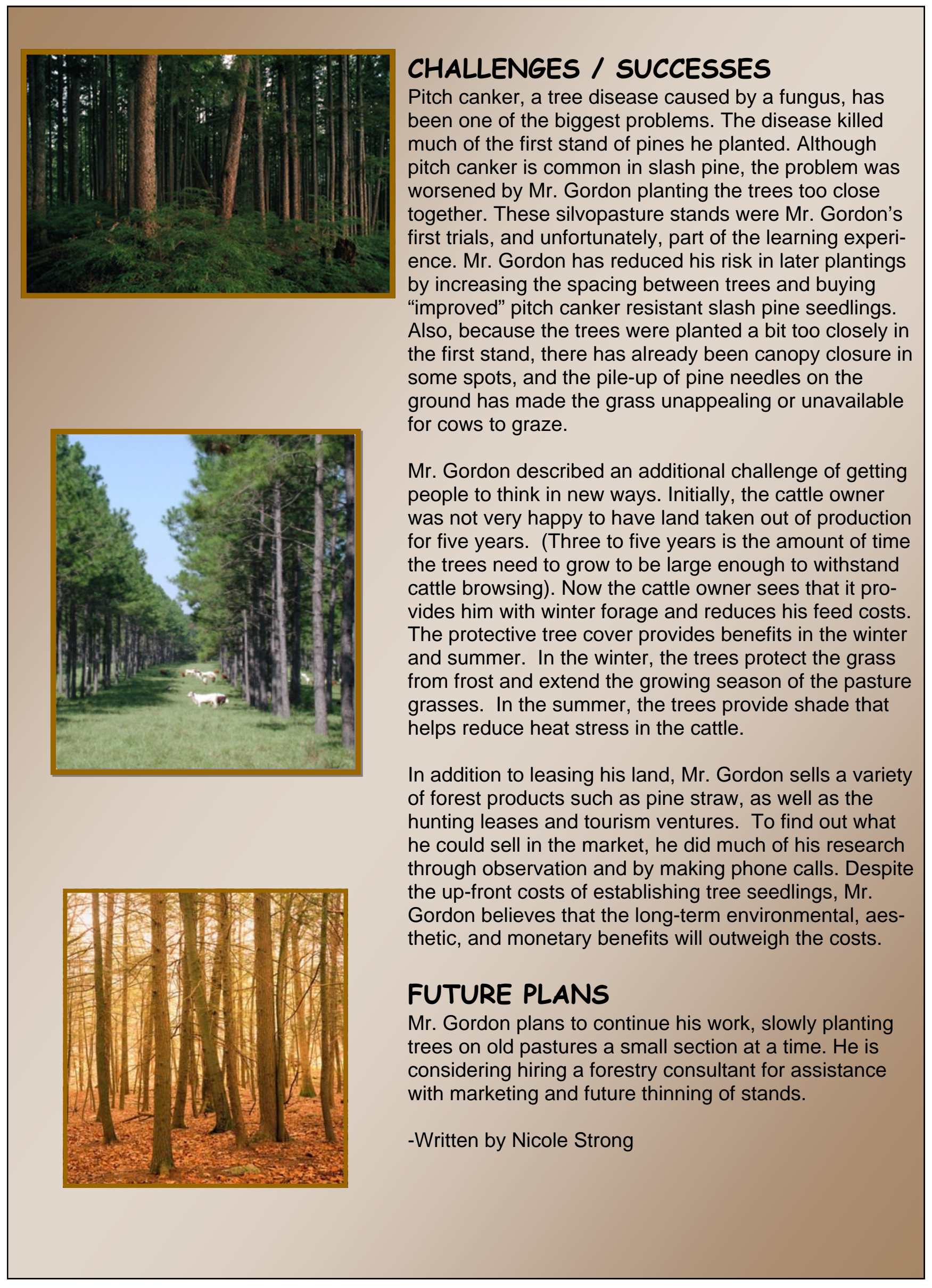




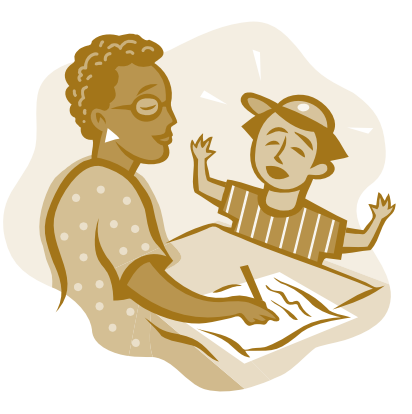

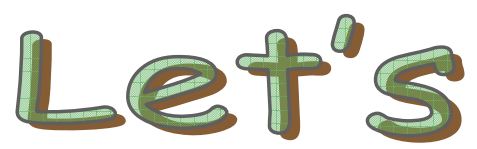

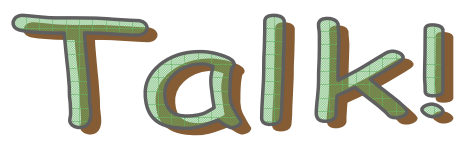

\section{Share with your helper}

Describe the land before and after the agroforestry practice was installed.

$\checkmark$ Which way do you like the land better and why?

$\checkmark$ What type of agroforestry system is this?

\section{What's imporknnt?}

List the products harvested from the land managed in the agroforestry system.

What was added or removed (plants, animals, etc.) in the process of installing the agroforestry system?

Why did the land owner decide to manage land as an agroforestry system?

List two problems the land owner encountered from changing over to agroforestry.

\section{What have you learned?}

What would you have done the same? Differently?

Why is it helpful to learn from another person's experiences?

\section{Imagine what's nert!}

How could you use this information and additional land owner's experiences to help others?

In what other situation would reading a case study aid in learning?

In what other professions would you use case studies as part of your job?

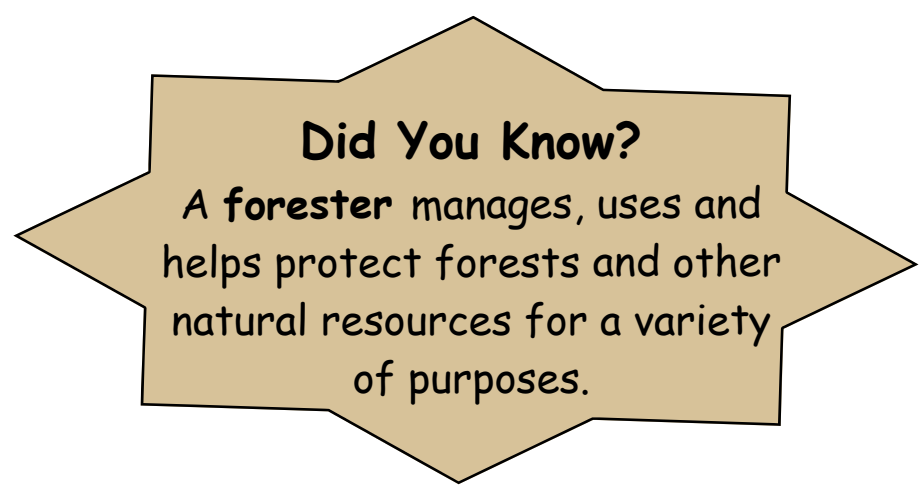




\section{Idemetitiving A Agroforestiny on Yours OWy}

Now that you know about each agroforestry practice, your task is to identify and photograph your own examples of four of the five practices to share with others. Think about where you can find examples of each in your community or nearby communities. For example, riparian forest buffers can be found along rivers, ditches, canals, lakes, and streams. Can you find cattle grazing in the shade of trees? Often, land owners may manage their land unintentionally with an agroforestry design. However, these landowners may be able to make more money and better use of their land if they are familiar with these agroforestry strategies.

Your county extension agent may be the best person to contact to begin your search. They will know some of the land owners in your area and how they manage their land.

\section{Compile a set of pictures of four of the five} practices. Try first to take your own photographs of agroforestry in your community. Second, if you cannot find examples in your community, find pictures on-line to print.

2. Record and communicate your findings. You may need to ask the land owner to help you answer some of the questions if the answers are not apparent.

\section{For each practice:}

$\checkmark$ Take photographs on location, or print out picture from the internet

$\checkmark \quad$ Identify and label the picture

$\checkmark \quad$ List the specific products from the site

$\checkmark$ List two human or environmental benefits

$\checkmark$ List two potential challenges

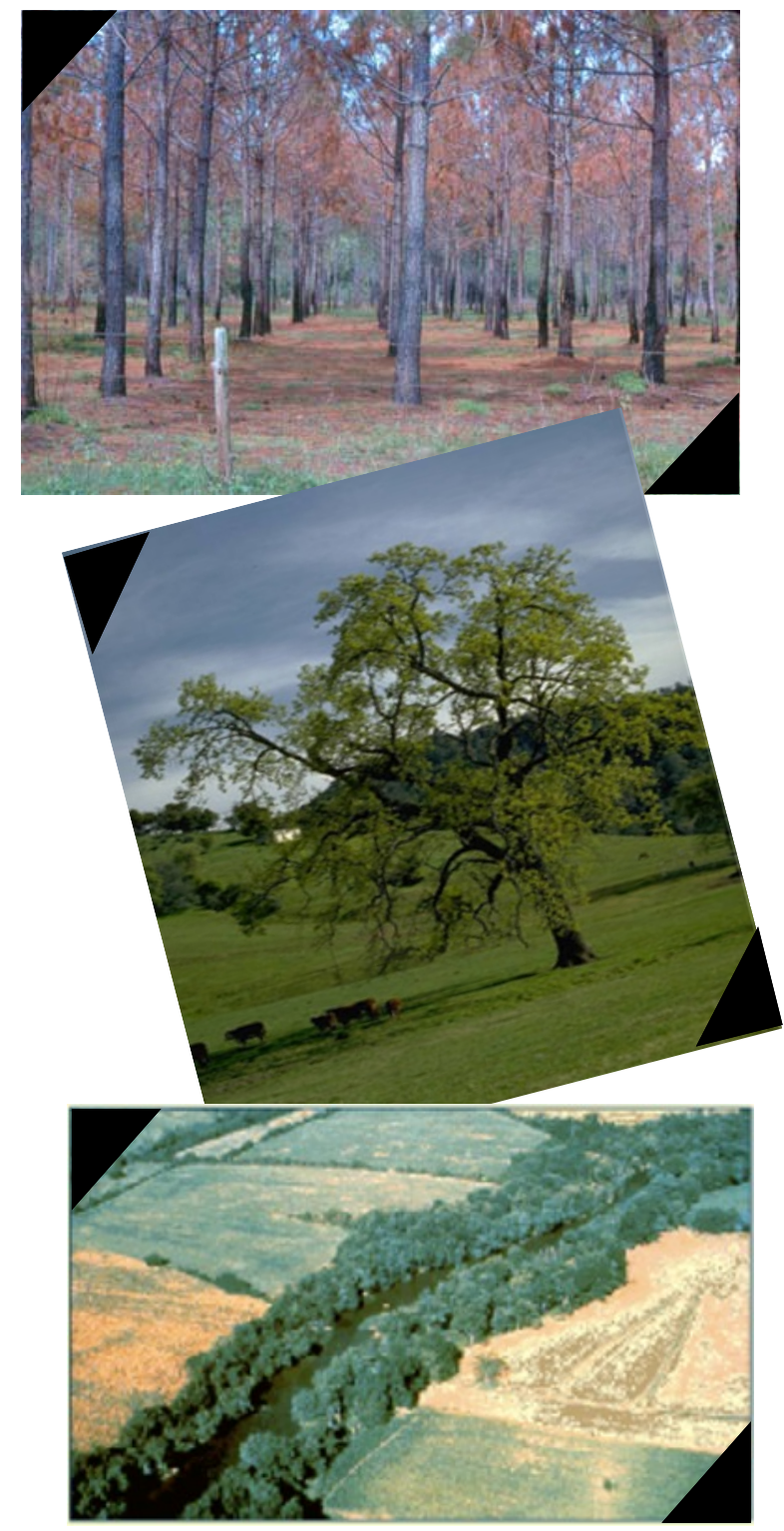




\section{Practicing Agroforestry}

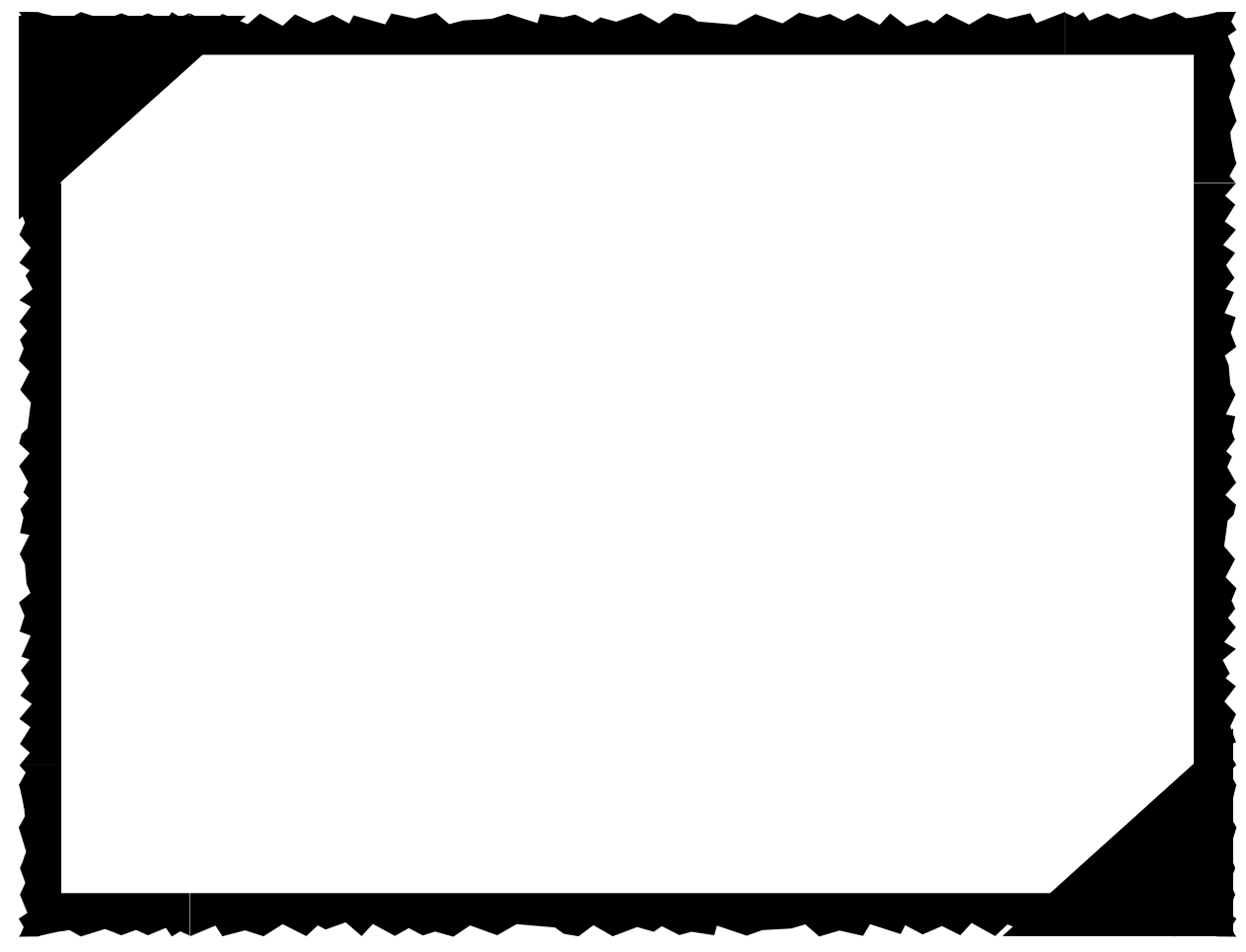

Practice:

Human/Environmental Benefits:

Potential Challenges:

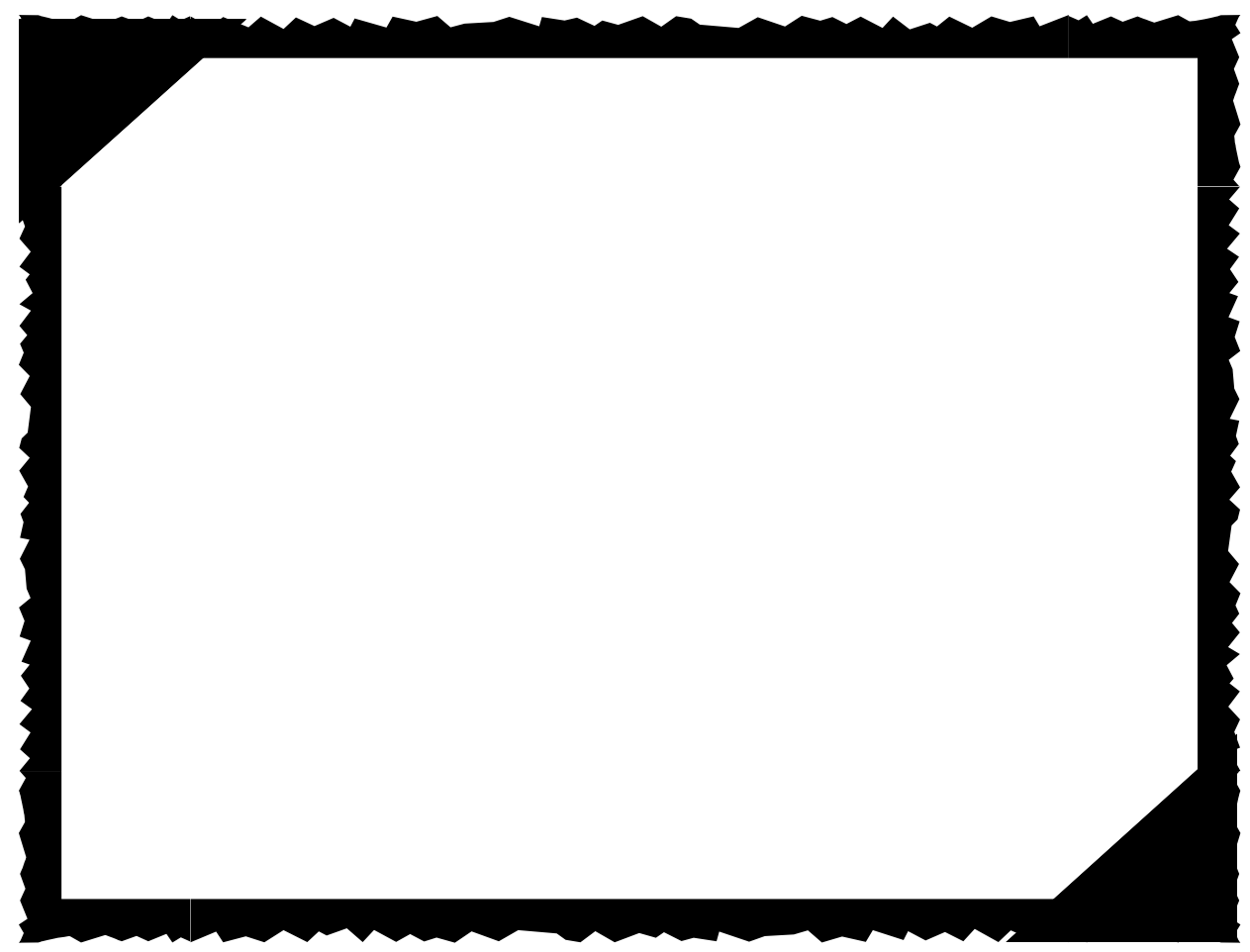

Practice:

Location:

Human/Environmental Benefits:

Potential Challenges: 


\section{in My Community}

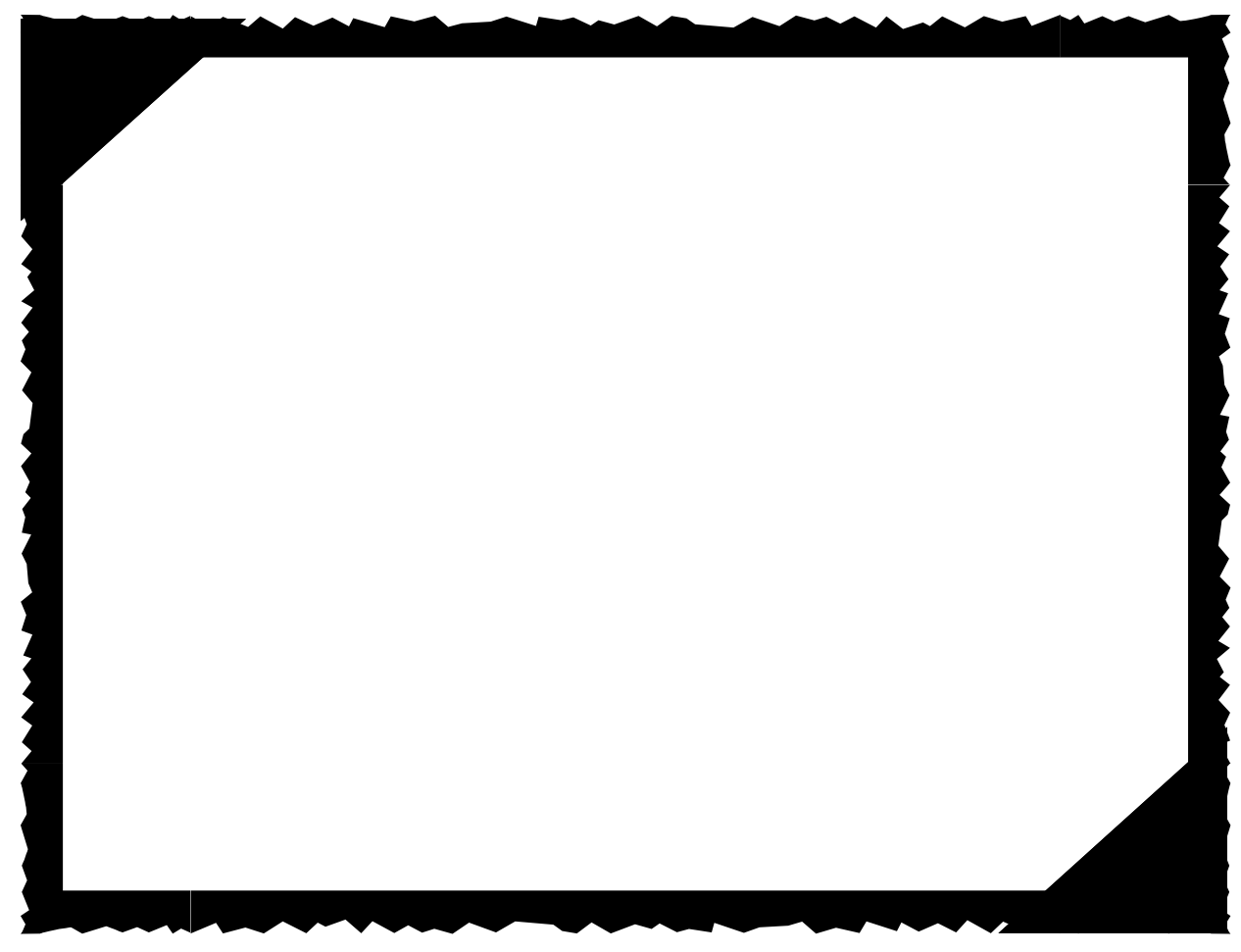

Practice:

Location:

Human/Environmental Benefits:

Potential Challenges:

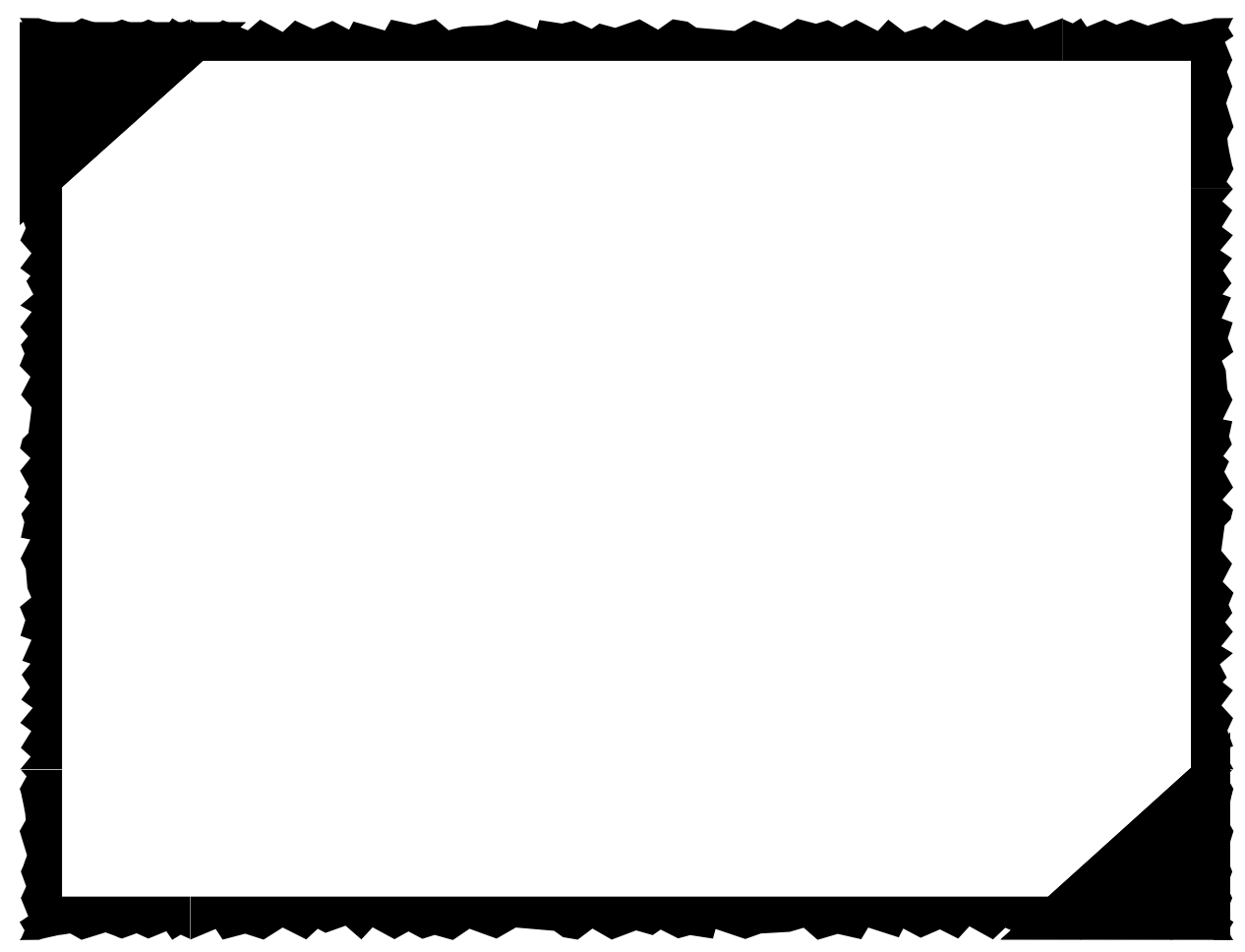

Practice:

Location:

Human/Environmental Benefits:

Potential Challenges: 


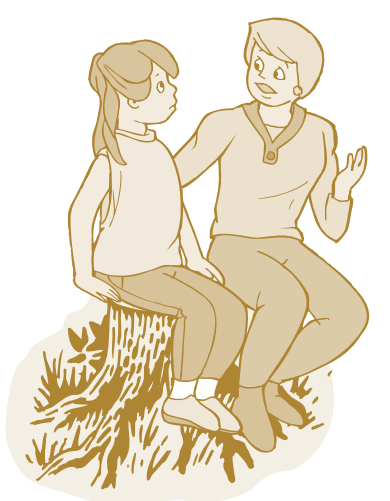

\section{What's imporkant?}

Which agroforestry system is most popular in your area? Why do you think that is?

Describe how an agroforestry system might change over time.

\section{What have you learned?}

What could agroforestry systems provide for your local community that traditional land management would not?

\section{Imagine what's ner!!}

Do you think more land owners would use agroforestry if they knew about it? Why or why not?

How can you use photography to communicate findings with others?

What could you do to communicate what you have learned about agroforestry with others?

What do they provide for the State of Florida?

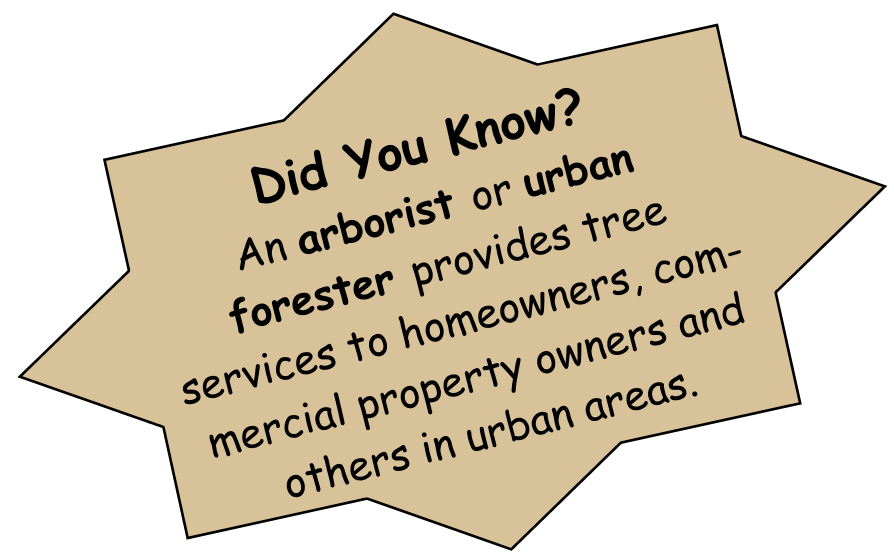




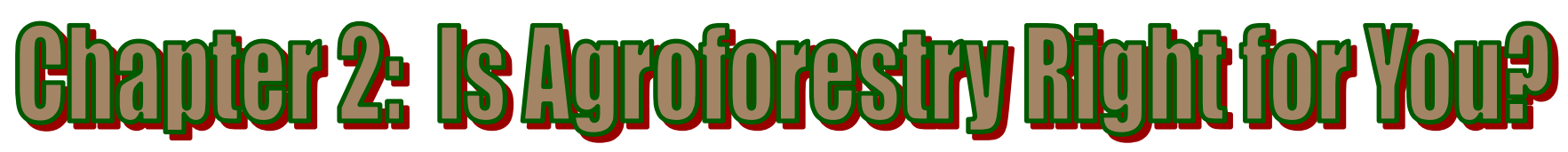

The next three activities will help you become a good decision maker to determine if agroforestry is right for an area.

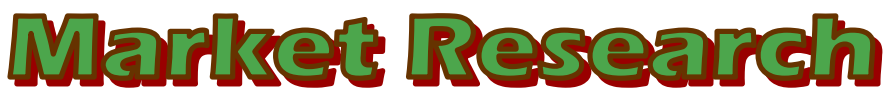

The land owner faces many decisions when deciding on a new management plan. One of the largest decisions is which products to grow. The possibilities may seem endless - how do you choose? One of the most important things a land owner can do before starting to grow anything new is to investigate the market: the opportunity to sell specific products. One key element of the market is the buyer. Market research involves finding out what people need and want that is not currently being sold or not available in sufficient quantities. A survey can be conducted in order to identify the products that will bring the farmer the greatest success. The survey should be conducted in the same places the products will be sold. Some of these places may include: Farmers markets, Roadside stands, Grower cooperatives, Grocery stores, Restaurants/ health food stores.

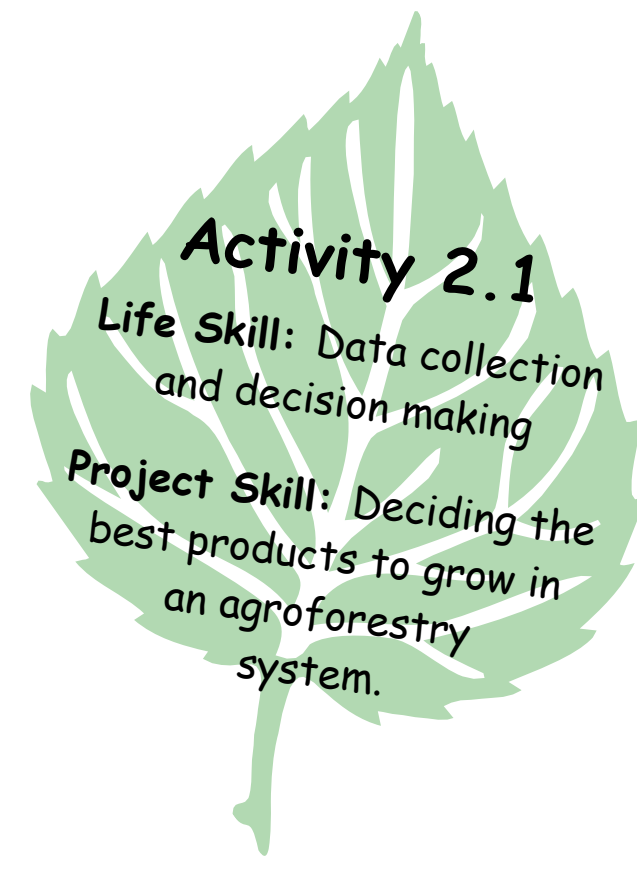

\section{A Trip to the Farmer's Market!}

Pretend you own 100 acres suitable for agroforestry. You want to select products to grow in your agroforestry system that are in demand. In order to find out what products you should grow in your agroforestry system, you will conduct your own market research. The most common and accessible location for small farmers to sell their products is at the farmers market. Find the closest farmers market online at: http://www.ams.usda.gov/farmersmarkets/map.htm

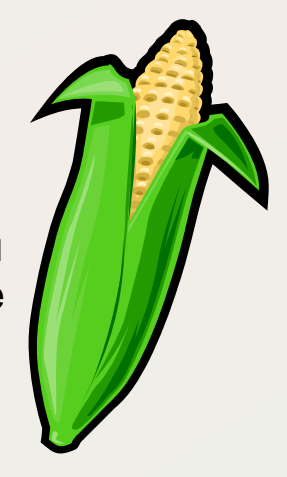

With help from the guidelines below, design your own survey.

1. The survey should be in an interview format.

2. The questions will be divided into two surveys for the: a) farmers and b) buyers.

3. Each section should be five to ten questions. Ten questions should be the maximum to keep the survey brief, yet beneficial.

Keep in mind that you want your survey to reveal the answer to your question. "What should I grow in my agroforestry system?" 


\section{Example questions to ask farmers:}

- What can you sell here? What can you not sell here?

- What do you add value to (such as make fruit into jelly) and why do you add value?

- How do you attract people to your product?

- Do you do anything to make your product different?

- What products do you usually sell out of?

- What products do you never sell out of?

- Is there a product that people buy that is not produced locally, but can be?

- Is there something that people would like to buy, but is not available?

- Do purchasers express any concerns about buying food products here?

- Your own questions

\section{Example questions to ask buyers:}

- What do you buy at the farmers market?

- What would you like to buy here that is not sold here?

- What product(s) sell out that can be hard to buy?

- Do you have a concern about food products?

- What is your favorite reason for coming to the farmers market?

- Your own questions

Once you have designed your farmer's market survey, test the questions on a family member or friend. This is a good practice to make sure the questions are understood clearly by the people taking the survey.

\section{Be sure to:}

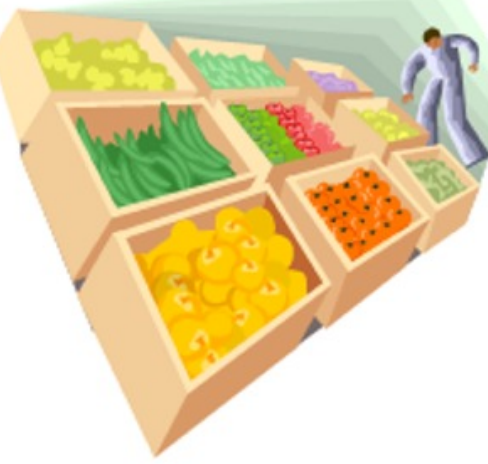

- Keep the farmer and buyer surveys on separate pieces of paper

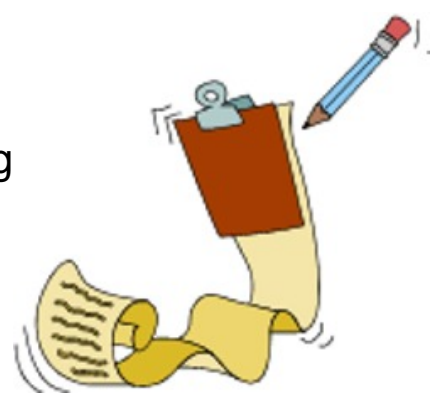

- Make 10 copies of each (front and back to conserve paper!)

Now at the farmers market, you will be nothing less than a professional! You are ready to conduct your survey. Grab your clip board and pen and head out to the farmers market. Survey five to ten farmers and five to ten buyers. 

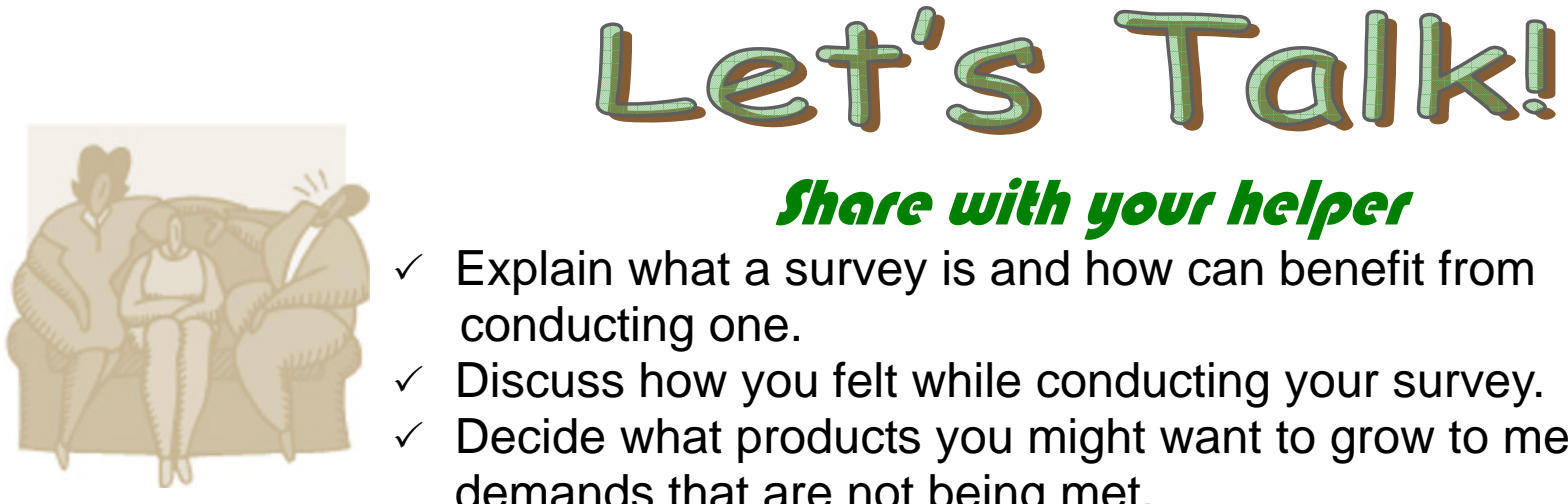

\section{Share with your helper}

$\checkmark$ Explain what a survey is and how can benefit from conducting one.

$\checkmark$ Discuss how you felt while conducting your survey.

$\checkmark$ Decide what products you might want to grow to meet market demands that are not being met.

\section{What's imporkant?}

What products sell well? Why?

What products do not sell well? Why?

\section{What have you learned?}

How did farmers "add value" to their products? Why?

What do buyers care about? Why?

\section{Imagine what's nert!}

Describe one way you could attract people to your agroforestry product at the farmers market.
In addition to the farmer's market, in what other sites could you survey owners/producers and buyers?

In what careers could you use the skills you've practiced with this project activity?

\section{more challenges}

In order to make your product stand out from the rest, create a poster to put at your stand at the farmer's market to advertise your product. Or offer to make a poster for a farmer at the market.

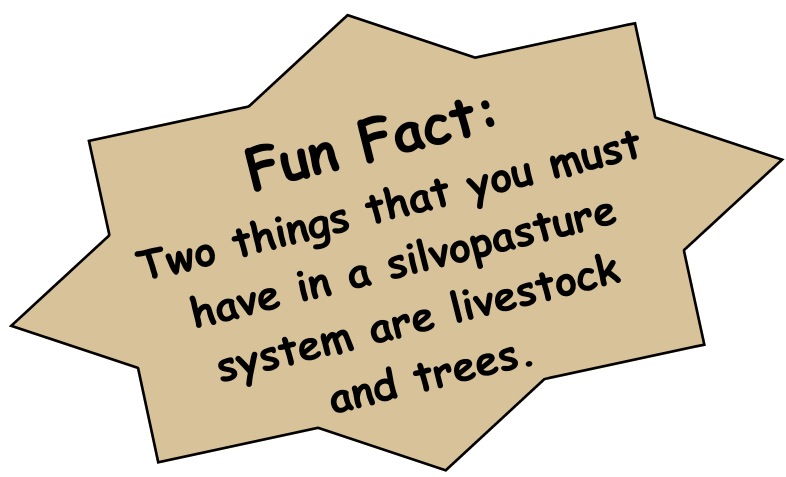




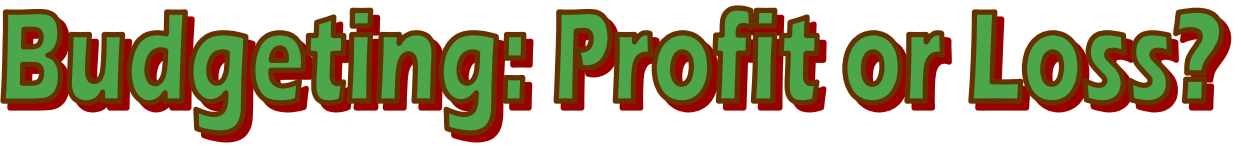

During the planning phase of any business, the manager creates a budget of what she or he expects to spend and earn. This will help the owners decide if the planned business will actually make money and how many years it will take to start making a profit. In addition to businesses, an individual or a family may work on a budget to determine if there will be any money after they pay the bills to buy something special.
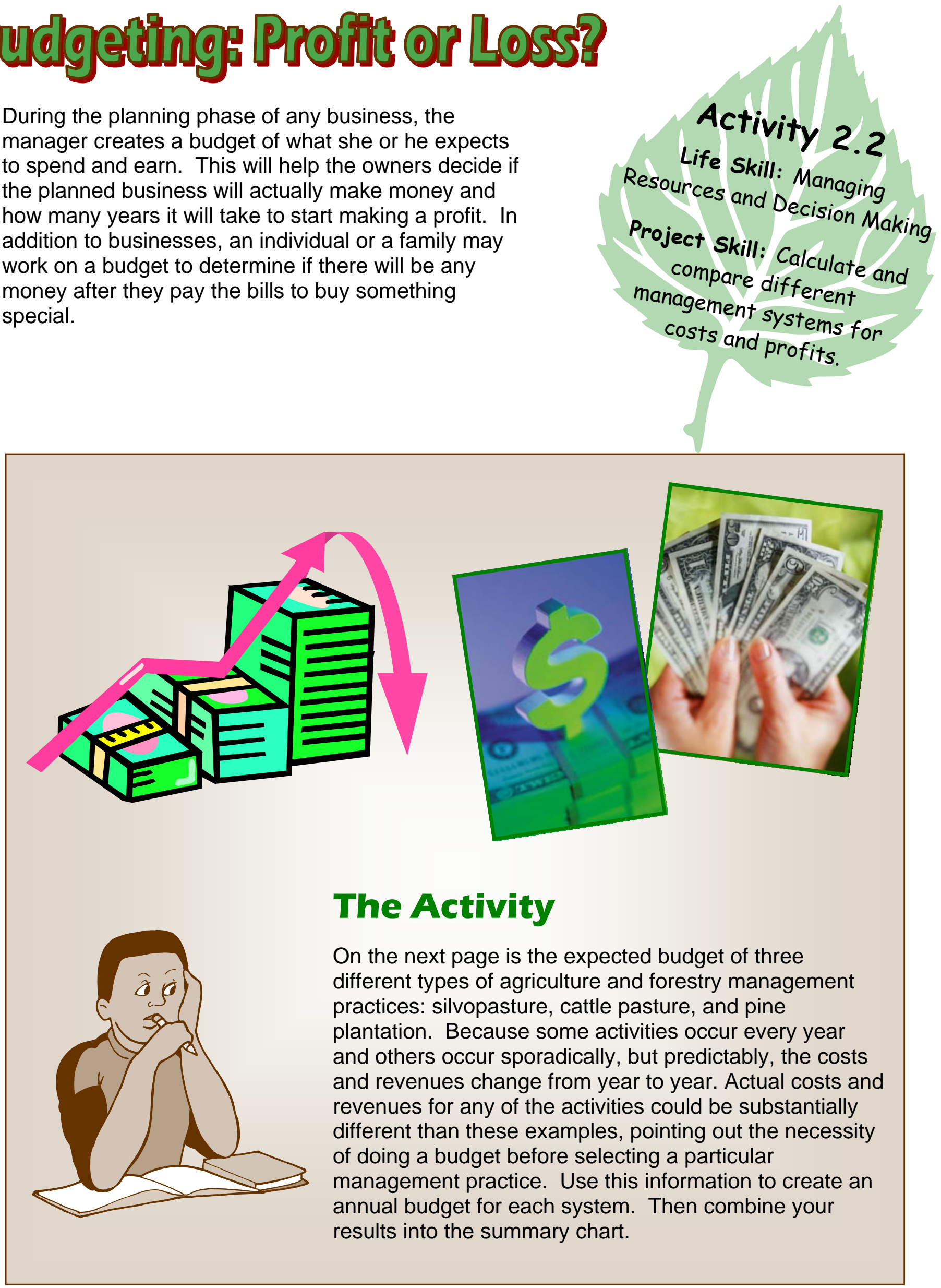
Calculate an annual budget for each agroforestry system using the expected costs and revenue presented.

\section{Silvopasture System}

\begin{tabular}{|c|c|c|c|}
\hline Year & Costs & Revenue & Net profit \\
\hline 1 & & & \\
\hline 2 & & & \\
\hline 3 & & & \\
\hline 4 & & & \\
\hline 5 & & & \\
\hline 6 & & & \\
\hline 7 & & & \\
\hline 8 & & & \\
\hline 9 & & & \\
\hline 10 & & & \\
\hline 11 & & & \\
\hline 12 & & & \\
\hline 13 & & & \\
\hline 14 & & & \\
\hline 15 & & & \\
\hline 16 & & & \\
\hline 17 & & & \\
\hline 18 & & & \\
\hline 19 & & & \\
\hline 20 & & & \\
\hline
\end{tabular}

Silvopasture System Sample Budget

\begin{tabular}{|l|l|l|l|}
\hline Year & Activity & Cost \$/acre & Income \$/acre \\
\hline 0 & Establishment of trees and forage & 250 & \\
\hline $1-20$ (annual) & Forage maintenance & 30 & \\
\hline $4-15$ (annual) & Cattle purchase/care \& sales & 350 & 510 \\
\hline 15 & Thinning trees & & 200 \\
\hline $4,8,12,16,20$ & Prescribed burn & 15 & \\
\hline 20 & Final harvest & & 1000 \\
\hline $0-20$ (annual) & Property tax & 10 & \\
\hline
\end{tabular}




\section{Cattle Pasture System}

\begin{tabular}{|l|l|l|l|}
\hline Year & Costs & Revenue & Net profit \\
\hline 1 & & & \\
\hline 2 & & & \\
\hline 3 & & & \\
\hline 4 & & & \\
\hline 5 & & & \\
\hline 6 & & & \\
\hline 7 & & & \\
\hline 8 & & & \\
\hline 9 & & & \\
\hline 10 & & & \\
\hline 11 & & & \\
\hline 12 & & & \\
\hline 13 & & & \\
\hline 14 & & & \\
\hline 15 & & & \\
\hline 16 & & & \\
\hline 17 & & & \\
\hline 18 & & & \\
\hline 19 & & & \\
\hline 20 & & & \\
\hline
\end{tabular}

\section{Cattle Pasture System Sample Budget}

\begin{tabular}{|l|l|l|l|}
\hline Year & Activity & Cost \$/acre & Income \$/acre \\
\hline 0 & $\begin{array}{l}\text { Establishment of } \\
\text { forage }\end{array}$ & 115 & \\
\hline $1-20$ (annual) & Forage maintenance & 30 & \\
\hline $2-20$ (annual) & $\begin{array}{l}\text { Cattle purchase/care } \\
\& \text { sales }\end{array}$ & 350 & 525 \\
\hline $\begin{array}{l}2,4,6,8,10,12, \\
14,16,18,20\end{array}$ & Prescribed burn & 5 & \\
\hline $0-20$ (annual) & Property tax & 10 & \\
\hline
\end{tabular}




\section{Pine Plantation System}

\begin{tabular}{|c|c|c|c|}
\hline Year & Costs & Revenue & Net profit \\
\hline 1 & & & \\
\hline 2 & & & \\
\hline 3 & & & \\
\hline 4 & & & \\
\hline 5 & & & \\
\hline 6 & & & \\
\hline 7 & & & \\
\hline 8 & & & \\
\hline 9 & & & \\
\hline 10 & & & \\
\hline 11 & & & \\
\hline 12 & & & \\
\hline 13 & & & \\
\hline 14 & & & \\
\hline$\overline{15}$ & & & \\
\hline 16 & & & \\
\hline 17 & & & \\
\hline 18 & & & \\
\hline 19 & & & \\
\hline 20 & & & \\
\hline
\end{tabular}

Pine Plantation System Sample Budget

\begin{tabular}{|l|l|l|l|}
\hline Year & Activity & Cost \$/ac & Revenue \$/ac \\
\hline 0 & Establishment of trees & 200 & \\
\hline $10-20$ (annual) & Hunting lease & & 10 \\
\hline $8,9,10,11,12$ & Pine straw & & 70 \\
\hline 15 & Thinning trees & & 500 \\
\hline $4,8,12,16,20$ & Prescribed burn & 15 & \\
\hline 10,15 & Fertilization & 80 & \\
\hline 20 & Final harvest & & 2000 \\
\hline $0-20$ (annual) & Property tax & 10 & \\
\hline
\end{tabular}




\section{Summary}

\begin{tabular}{|l|l|l|l|}
\hline Years & $\begin{array}{l}\text { Silvopasture } \\
\text { Net profit \$lacre }\end{array}$ & $\begin{array}{l}\text { Cattle Pasture } \\
\text { Net profit \$lacre }\end{array}$ & $\begin{array}{l}\text { Pine Plantation } \\
\text { Net profit \$lacre }\end{array}$ \\
\hline $0-5$ & & & \\
\hline $6-10$ & & & \\
\hline $7-15$ & & & \\
\hline $16-20$ & & & \\
\hline $0-20$ & & & \\
\hline
\end{tabular}

\section{How would the budget change if:}

1. In year eight and on, the state passed a regulation that allows farmers to sell environmentally friendly meat for extra money. All farms with silvopasture will increase the cattle sales by $\$ 75$ per acre.

2. In year five and on, the state passed a regulation that gives a tax break on farms that practice environmentally friendly management. All farms with silvopasture reduce property tax from \$10 to $\$ 5$ an acre. 


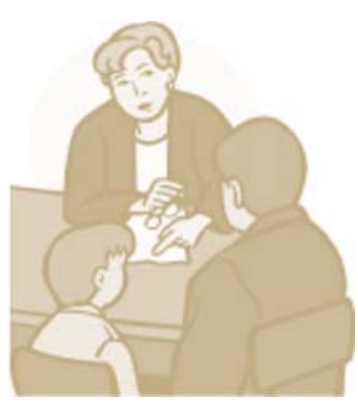

\section{What's imporkant?}

What information did you find out from calculating the budgets? How is this information useful?

Name some additional costs not included in the example budget for each type of system.

\section{What have you learned?}

Which system protects water quality the best?

Which system may cause the most water quality problems and what can you add to that system to protect water quality?

What could be changed to make the least profitable operation more profitable?

\section{Imagine what's nest!}

Why is it important to plan a budget in advance?

What can you make a budget for at your school or at your home?

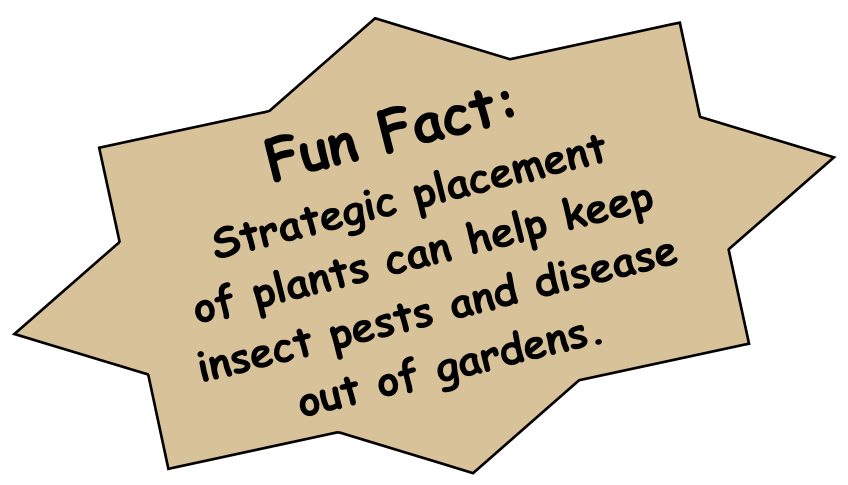




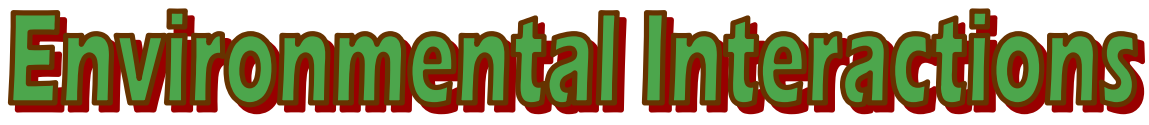

The ecological interactions between trees, crops, and livestock are important reasons for using agroforestry systems. Some agroforestry systems are simple and form only a few connections. Others are so complex they may look more like a natural system than a managed area. If properly planned, these interactions are what create many of agroforestry's benefits. These interactions can also cause problems such as competition for sunlight, water, and nutrients between trees and crops. This game will introduce you to some of the basic biological factors in agroforestry. These interactions are what farmers want to keep in mind while planning their agroforestry system.
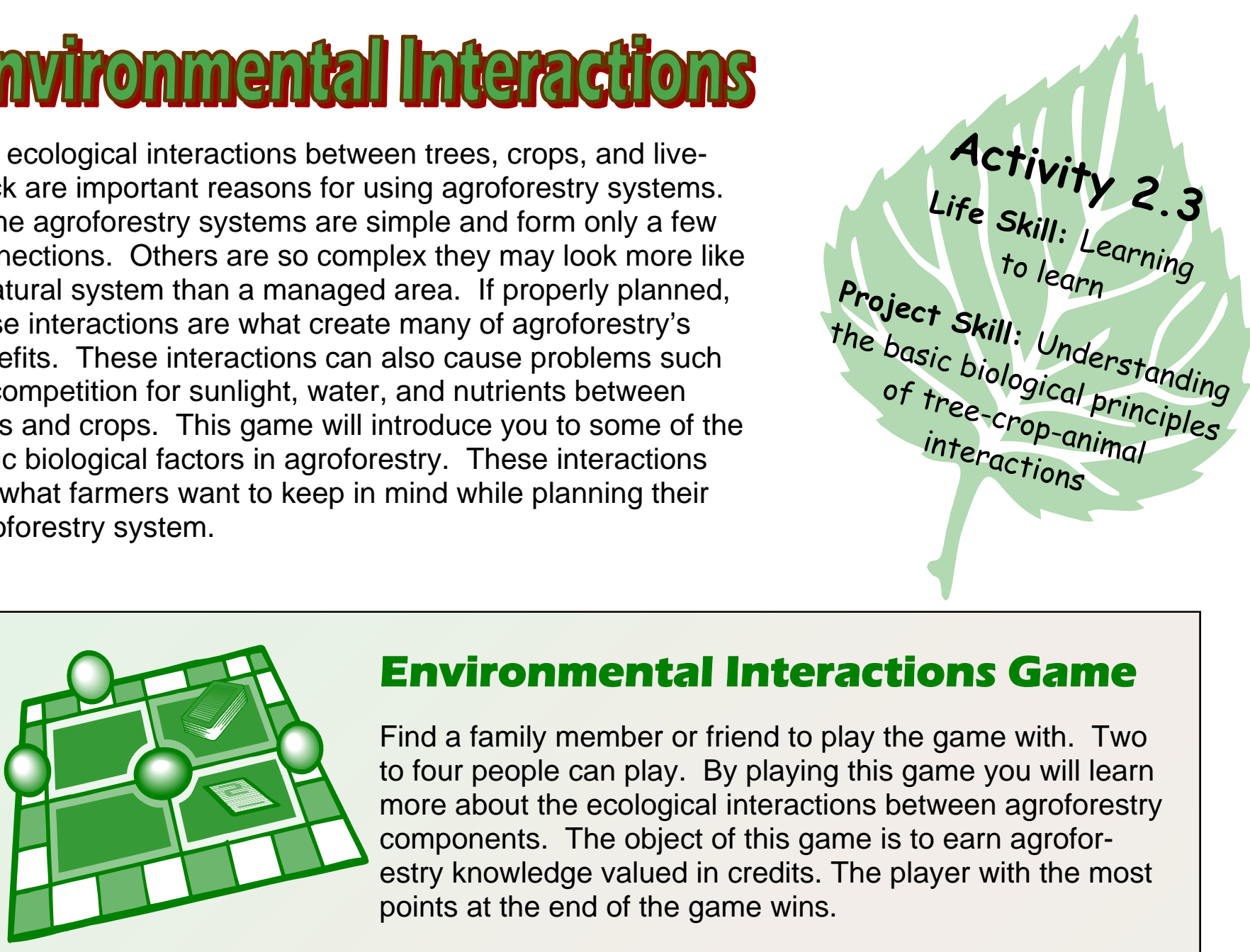

\section{Environmental Interactions Game}

Find a family member or friend to play the game with. Two to four people can play. By playing this game you will learn more about the ecological interactions between agroforestry components. The object of this game is to earn agroforestry knowledge valued in credits. The player with the most points at the end of the game wins.

\section{Directions:}

1. Each player needs a game piece to move through the agroforestry board. You can use different coins, such as a penny, nickel, or quarter.

2. Shuffle the Environmental Interaction cards well and place the phrases pointing down on the board.

3. Use a piece of notebook paper to keep a tally of your agroforestry credits.

4. All players put game pieces on start square.

5. Draw a card and move to the next square that corresponds with the AF system on your card. Read the card aloud and record your credits earned or lost on the tally sheet.

6. Take turns until the first person reaches "Finish" - any AF card can get you into the finish square. First person that reaches "Finish" earns 20 bonus credits.

7. Once all the players are done, count up the credits for each player.

The person with the most credits earns the title, "Master Agroforester"

$2^{\text {nd }}$ place, "Advanced Agroforester"

$3^{\text {rd }}$ place, "Intermediate Agroforester"

$4^{\text {th }}$ place, "Beginner Agroforester" 


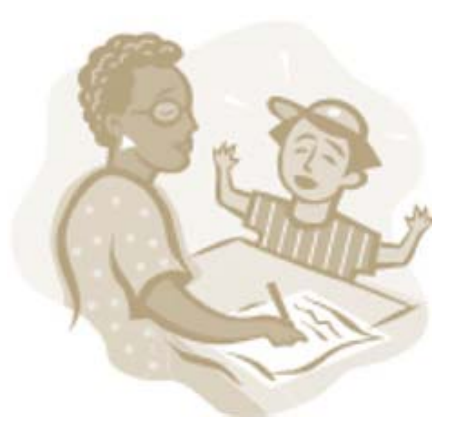

\section{What's important?}

Name three risks a land owner needs to keep in mind while designing their agroforestry plot.

What might be the most important interactions in your area and for the farmers you surveyed?

\section{What have you learned?}

How might these interactions be important for the farmers you surveyed?

How could you change agroforestry designs to reduce the effects of the different "con" cards?

\section{Imagine what's ney!!}

Other than in an agroforestry system, when may someone be concerned about biological interaction between plants and/or plants and animals?

In a town or city, how may trees affect their surroundings?

\section{More Ohallenges:}

Using the internet, find out how people use agroforestry in a different country. Possibly communicate with other 4-H groups abroad and ask how agroforestry is helping in their country. Write a newspaper article about your findings.

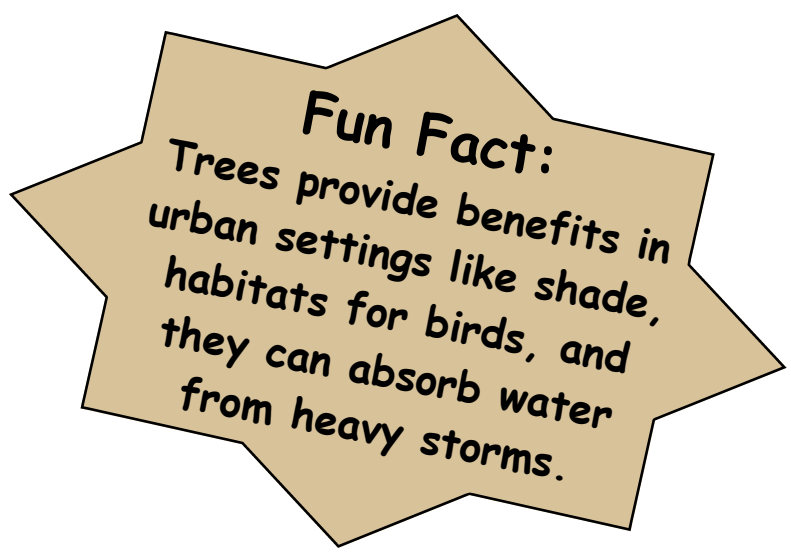




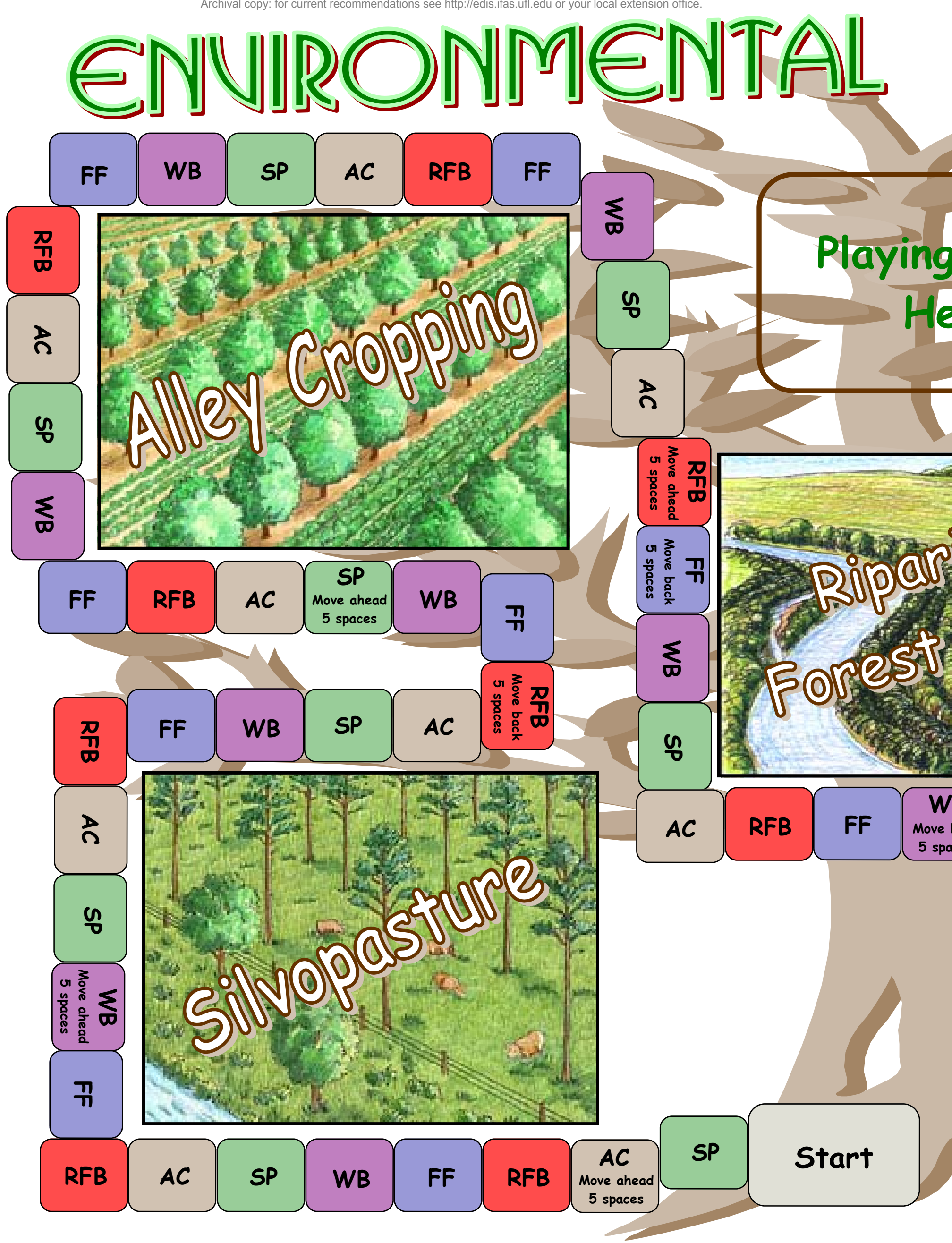




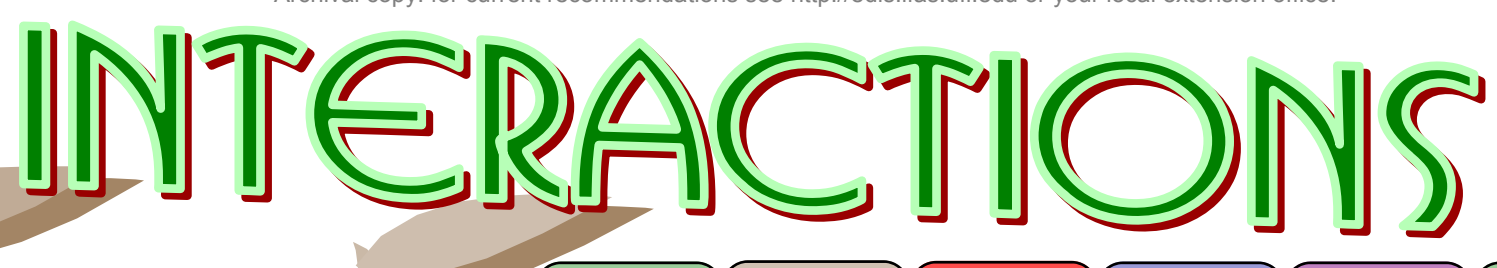

\section{Cards}

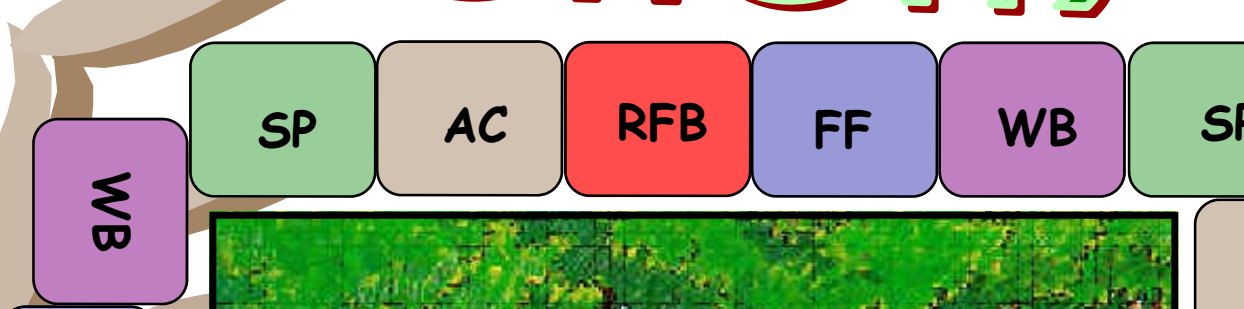

re

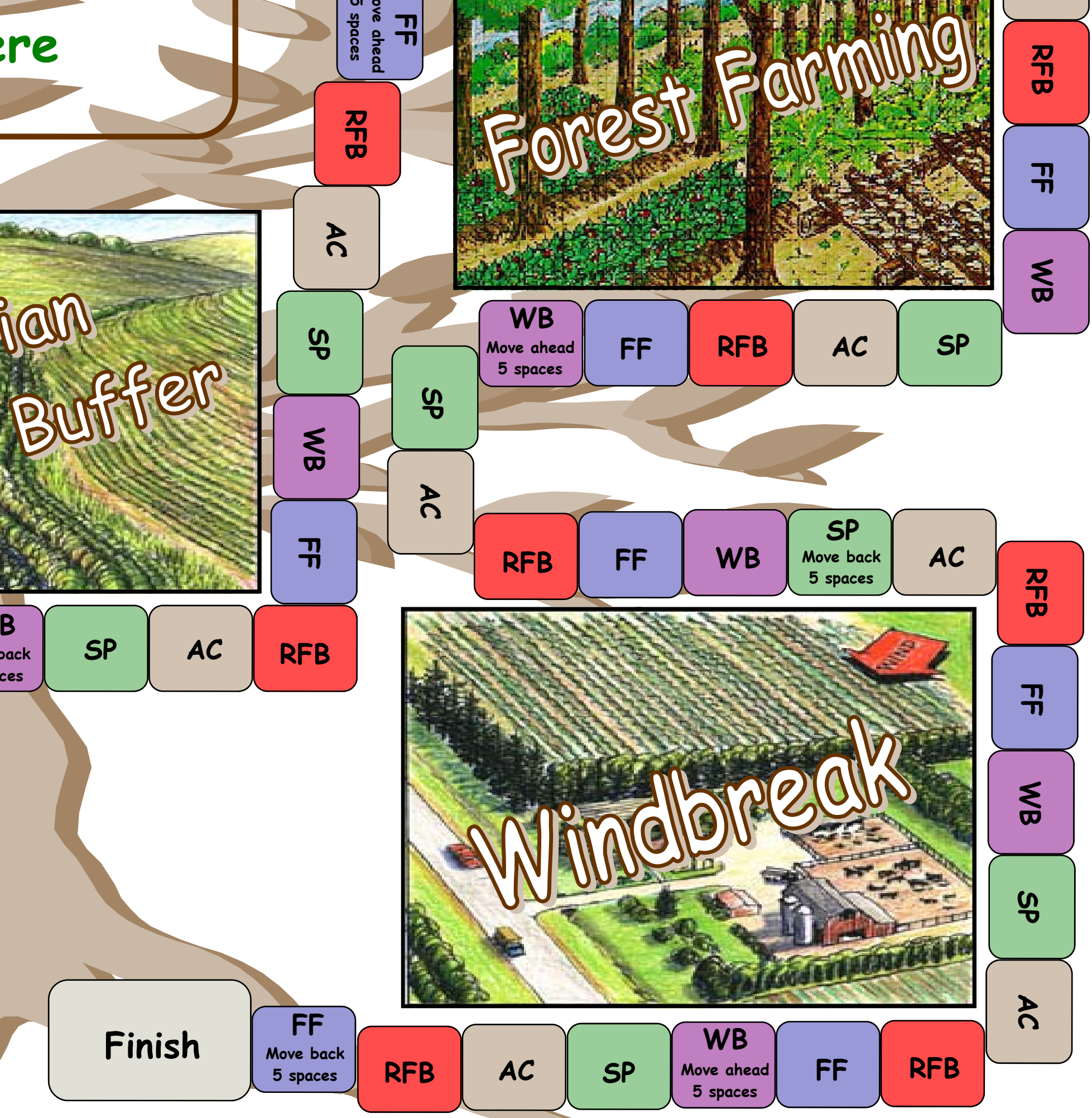



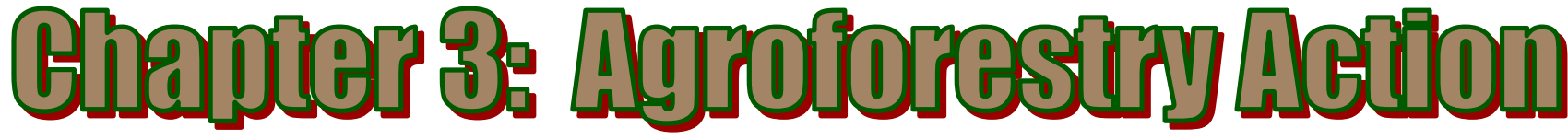

In the previous chapters, you have been introduced to the various way agroforestry can be applied to the land. Now that you understand the benefits and challenges of these practices, this chapter will allow you use this knowledge in addition to teaching others about agroforestry.

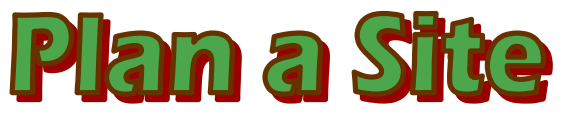

A management plan is a document created by land owners to guide and direct the use and management of land. In addition to private land owners, public and commercial lands all have a prescribed management plan. The goals of plans match the owner's objectives and can vary from recreation in a State Park to growing trees for lumber on a large tree plantation. When making plans, land owners, consultants, and other people often make a drawing or map that demonstrates how the plan will be laid out on the ground. This aids in allowing all people involved to discuss the plan together and make changes and additions they can agree on.

The beginning stages of the management planning process require the skills and knowledge you have gained in completion of this project book. Think about what you have learned in the project book and use this knowledge to make an agroforestry plan. You know:

1) What each agroforestry practice is used for.

2) What products come from each agroforestry practice.

3) What you learned from your market research.

4) What you learned from the interactions between trees-crops-animals.

\section{The Activity:}

Select one of the three land options on the next page. They include:

1) Hypothetical land situation in an urban area.

2) Hypothetical land situation in a rural area.

3) Pick a piece of land you are familiar with that would be suitable and benefit from agroforestry management.

Your task is to improve the land management practices using the agroforestry methods you learned. First, identify at least three management issues that need to be fixed, such as poor water quality, soil erosion, and income dependency on one crop. Then pick three different agroforestry systems you could use to fix the problems on the land. Make a diagram to explain how you designed the property. Label the types of trees, crops and animals you would use and why. You may need to do some research on the internet or make phone calls to extension agents find out what types or trees, crops and animals to use. Include a key or notes at the bottom to explain your strategies. 


\section{Aletivitivi Opritions}

Option \# 1 Urban area:

You live in the city and are assigned a project to demonstrate the benefits a retirement community.

The residents complain about the kids tromping on

There are three issues:

1) The residents live near a playg was something you could cural and would prefer not to put a fence in. ground. However, they want to keep their birds to their property.

2) The city park is of average size, with a pond in the midan the trees, there is not much vegetation in none of them near the pond on the prity park management It has too many nutrients from grass fertilizthe area except for graser is not clean enough for fish to live in
the pond water in droppings.

3) Some people in the retirement community would like to grow someth shade of the trees that fill in the backyard. However, the back yard doesn't get much light from the shade oft area.

\section{would like to make some town. After learning about a area:}

changes in your land management plans. to provide shadtle that graze on pasture. do not want to give up pasture area. that is ard from 50 to 150 cattle

middle of the pasture. something more with that land while in the the fifth year of growing. You would like to do
you harvest the trees. are still growing to make would like to do
more income until

\section{Option \#3:}

You pick out your own piece of land in order to design a basic agroforestry plan. 


\section{Agroforestry Action:}

Make your diagrams to explain how you designed the property. Label the types of trees, crops and animals you would use and why. Include a key or notes at the bottom to explain.

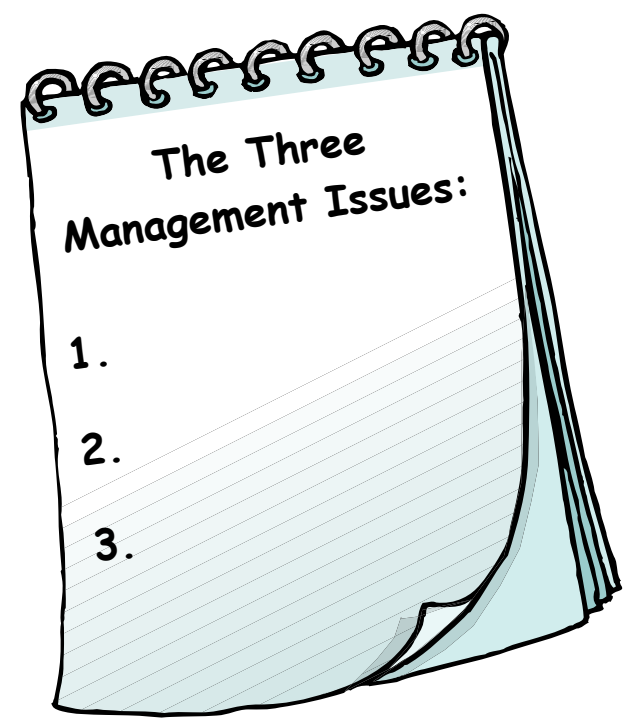


A Site Plan

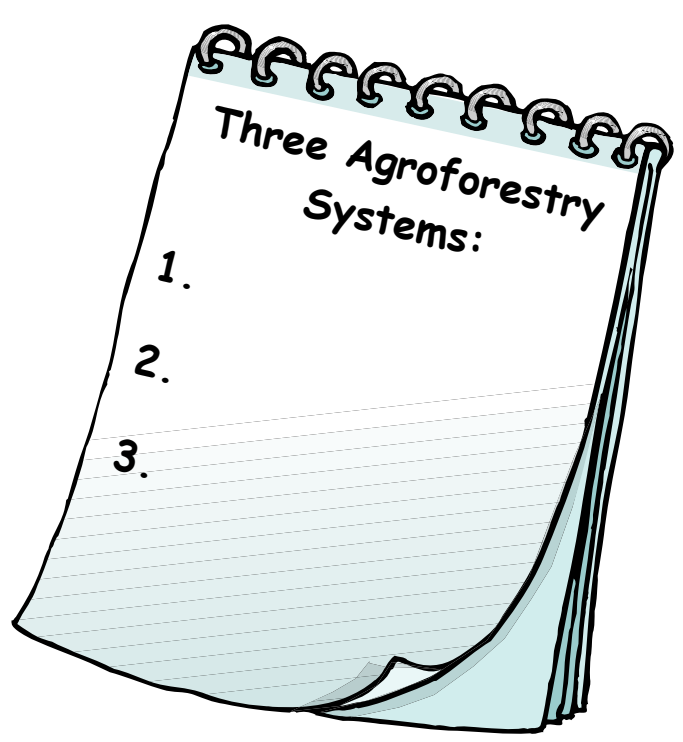

Use a key like this:

$\triangle=$ Pine Tree

)) = Creek

= Animal 


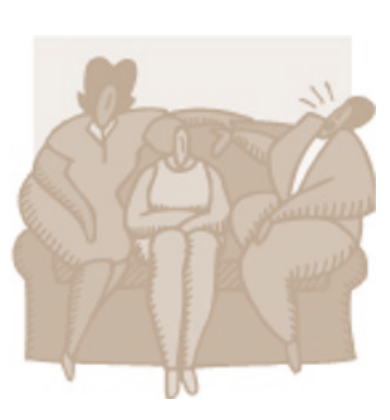

\section{What's imporknnt?}

What is the importance of making a plan before actually doing it?

What are important features of a diagram or map?

\section{What have you learned?}

Why did you choose the land option you selected?

What other agroforestry practices could you have used and what would you have done differently?
What are three important components of a new agroforestry practice the land owner needs to research before using it on their land?

\section{Imagine what's nest!}

Do you think management plans are flexible and can be changed as needs and trees grow taller or are harvested? Why?

In what other work can you use a diagram to explain a plan besides in land management?

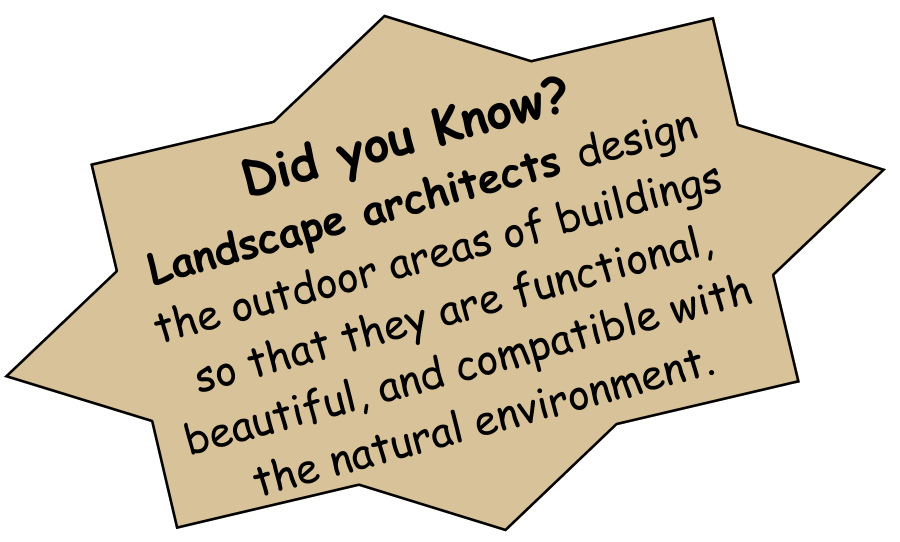




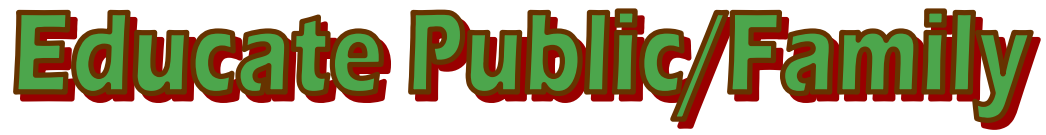

When a new technology or way of doing something is presented, sometimes it is slow to gain acceptance. Even though the benefits can be many, traditions and community norms are usually favored rather than trying something new. Think of something you and your family once used that is now considered old. Why did you stop using it? What convinced you to use the new technology?

Typically, people change their way of doing something when it benefits them and their family. Many companies try to persuade others to use their products by explaining how it will benefit the buyer. Think of agroforestry as a product. You understand the benefits of agroforestry and want to share this with others.
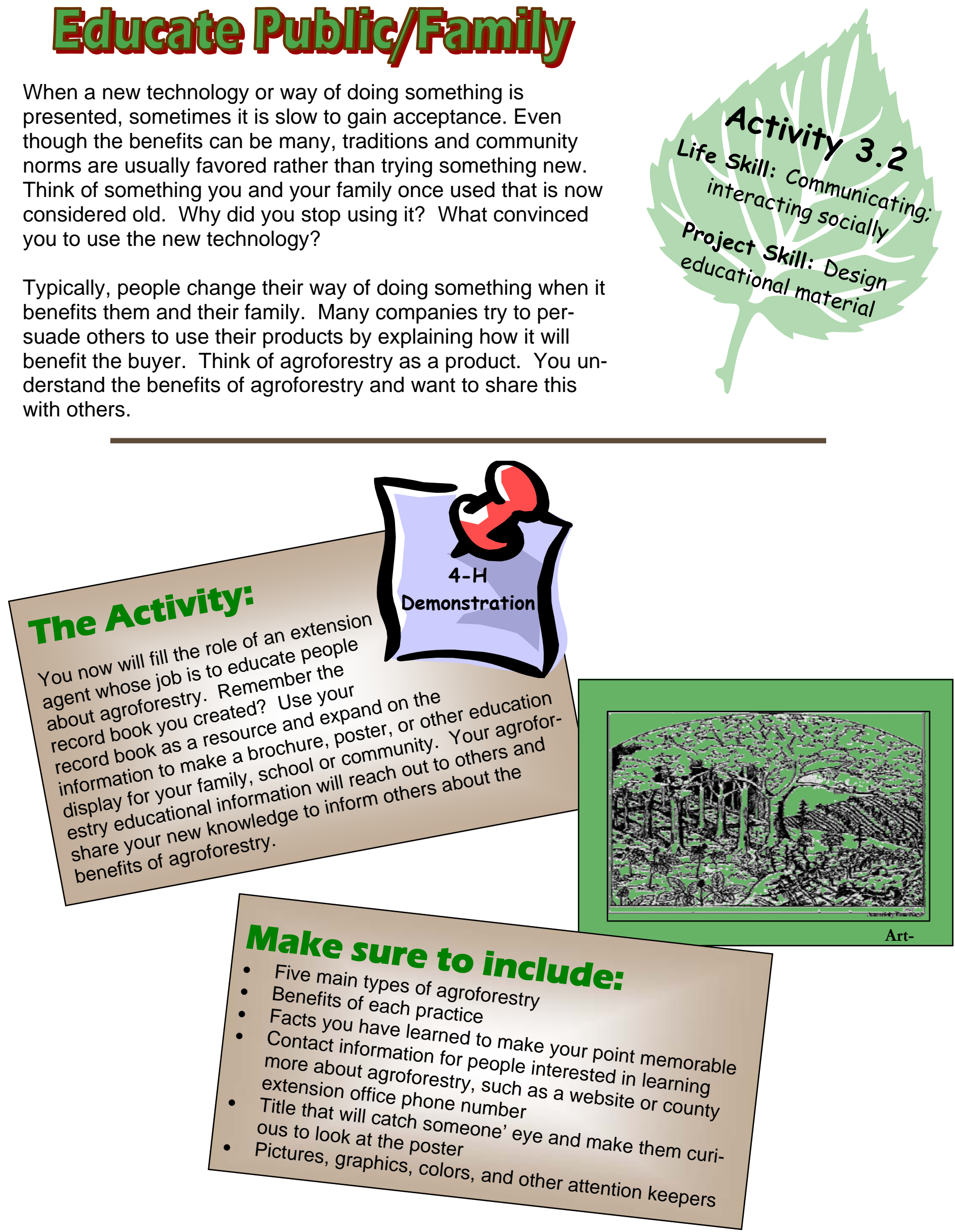


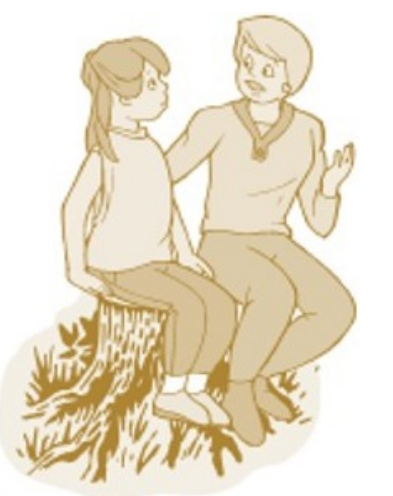

$\checkmark$ Discuss what type of educational material you chose and why you chose it.

$\checkmark$ Describe how you made your point convincing.

\section{What's important?}

Who and where will you display or distribute your educational material? Why?

How did you make your educational material fun to look at?
How do extension agents play a crucial role in communication between land owners?

\section{Imagine what's nert!}

Name different topics for an educational campaign you can create to share information you believe is important with others.

\section{What have you learned?}

What are the advantages of using a poster, brochure, or other similar methods of spreading information?

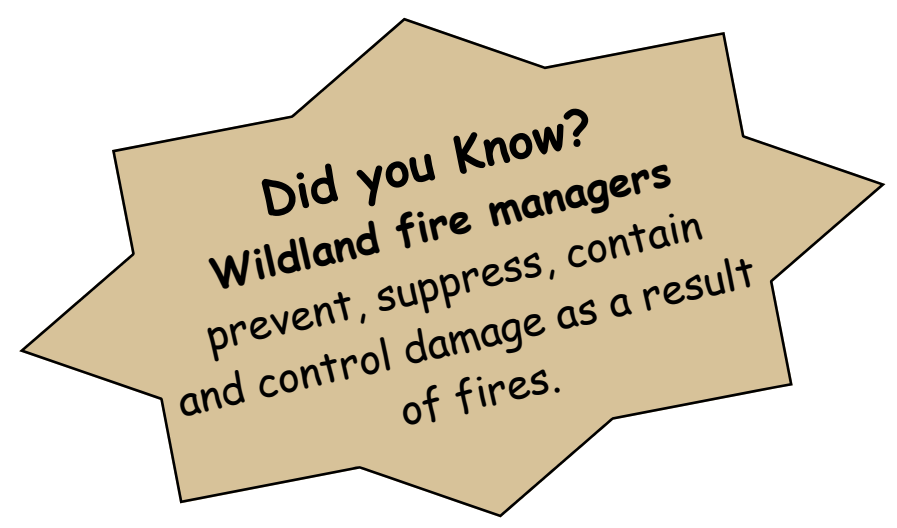




\section{Environmental Interactions Game Card Instructions}

\section{Prepare cards for each of these items or copy the card set from pages 28-31 of the Leader's Guide.}

\section{Alley Cropping cards}

- Trees in your alley cropping system protect against loss of topsoil and fertilizers, earn 10 credits.

- Leaves on the trees in your alley cropping system make a barrier against hard rain and prevent soil erosion, earn 5 credits.

- Deep roots of trees absorb fertilizers the crops missed and protect water quality, earn 10 credits.

- Planting more trees on your property increases bird habitat, earn 5 credits.

- Less manufactured fertilizers and insecticides are needed due to nutrient cycling in your agroforestry system, earn 10 credits.

- Birds you attract with extra trees eat insect pests, earn 5 credits.

- You use three types of agroforestry on your property which increases species diversity on your land, earn 5 credits.

- Your new agroforestry system efficiently uses less land but yields the same amount of products as before, earn 5 credits.

- Trees too close to crops and compete for nutrients, lose 5 credits.

- You did not choose plants that tolerate shade and your crop dies in the shady parts of your alley cropping system, lose 5 credits.

- You are not careful when spraying alley crops with pesticide and get it on the orange trees which damage your orange crop, lose 5 credits.

- You forgot to cut back limbs on your trees and there's too much shade on your crops, lose 5 credit.

- Water competition between your crops and trees yields a small crop, lose 10 credits.

\section{Silvopasture cards}

- Cows get relief from the hot sun in the shade of the trees of your silvopasture system, earn 10 credits.

- Your cows are happy because pasture is protected by the trees in your silvopasture system from frost which gives grass a longer growing season, earn 10 credits.

- Wildlife habitat improves by planting trees to make a silvopasture system on your property, earn 5 credits.

- You decide to use three types of agroforestry on your property which increases species diversity on your land, earn 5 credits.

- Your new agroforestry system efficiently uses less land but yields the same amount of products as before, earn 5 credits.

- Pine needles pile up on your pasture and cows have trouble grazing, lose 5 credits.

- Optimal soil conditions are not the same for trees and pasture, so your trees do not grow as fast in the silvopasture system as in a forest, lose 5 credits.

- You let your cattle graze in a pasture where you planted trees for silvopasture only one year ago and cattle trample tree seedlings, lose 10 credits.

\section{Forest Farming cards}

- You take advantage of the environmental conditions in your forest and grow ferns in the shade, earn 10 credits.

- You take advantage of the environmental conditions of your forest and grow mushrooms in the shade, earn 10 credits.

- Instead of building a structure to shade ornamental potted plants you grow to sell, you grow them in the shade of your forest, earn 5 credits.

- You decide to use three types of agroforestry on your property which increases species diversity on your land, earn 5 credits.
Alley Cropping ( $A C$ )

Trees in your alley cropping

system protect against loss

of topsoil and fertilizers.

\section{Earn 10 Credits}

\section{Sample Card from Leader's Guide}

- Animals eat part of your shiitake mushroom crop grown under the forest on your property, lose 5 credits.

- Birds eat blueberry fruits, lose 5 credits.

- You forget that crops must be shade tolerant to grow in the understory of the forest. You plant crops that need sun and they never grow, lose 10 credits.

\section{Riparian Forest Buffer cards}

- Look at that strong stream bank! Trees and other vegetation hold soil intact and prevent erosion and loss of land into the stream, earn 5 credits.

- Neighbor's agriculture fields flood from a recent storm, but you have riparian forest buffers along the stream of your property that absorbs the extra water and keep your crops safe, earn 10 credits.

- The water quality of the stream on your property improves greatly as roots in the riparian forest buffer filter and trap fertilizers and animal waste, earn 10 credits.

- The fish are happy in the stream on your property because the aquatic habitat improved after you planted a riparian forest buffer earn 5 credits.

- You plant mostly nut and berry producing trees and shrubs in your RFB which gives you money and environmental benefits, earn 5 credits.

- Birds eat fruits, lose 5 credits.

- You forget that crops must be shade tolerant to grow in the understory of the trees in your riparian forest buffer. You plant crops that need sun and they never grow, lose 10 credits.

\section{Windbreak cards}

- Breath deeply, less dust flies through the air after you plant windbreaks along the borders of your property, earn 10 credits.

- The windbreak you planted helped prevent frost damage and protects your crops, earn 5 credits.

- Animals get relief from hot sun in the shade of a windbreak, earn 5 credits.

- Planting more trees on your property increases bird habitat, earn 5 credits.

- The birds you attract with extra trees eat insect pests, earn 5 credits.

- You decide to use three types of agroforestry on your property which increases species diversity on your land, earn 5 credits.

- You forget to prune the trees in your windbreak and they grow tall. Shade intolerant crops die in the shade, lose 5 credits.

- You forget to keep animals away from tree seedlings you planted for a windbreak. Tree seedlings die from being trampled, lose 10 credits.

- You let your cattle graze in a pasture where you planted trees for silvopasture only one year ago. Cattle trample tree seedlings, lose 5 credits. 
Name:

Club:

County:

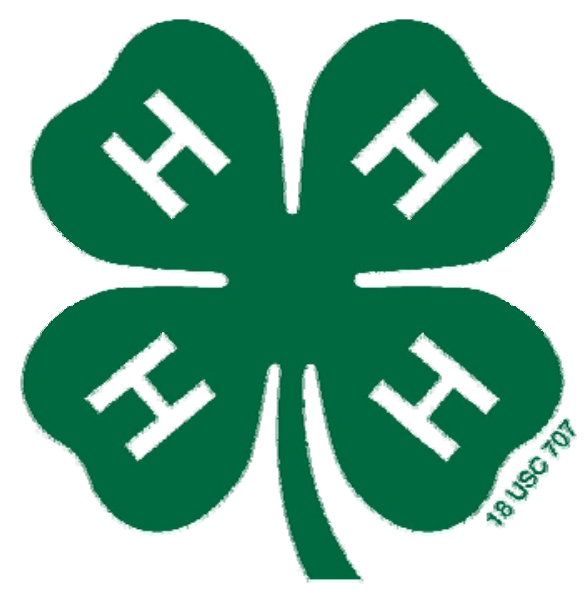

\title{
4-H Pledge
}

\author{
I Pledge: \\ My head to clearer thinking \\ My heart to greater loyalty \\ My hands to larger service, and \\ My health to better living \\ For my club, my country, and my world.
}

This publication was created by Julie Clingerman, Graduate Assistant, Alan Long, Associate Professor, School of Forest Resources and Conservation, Joy Jordan, Associate Professor/Curriculum Specialist, Department of Family, Youth \& Community Sciences, University of Florida, June 2005. Graphic Design by Laura Lok, Department of Family, Youth \& Community Sciences, University of Florida.

Special thanks to these reviewers Sharon Gamble, Extension Livestock Agent, Volusia County - Central; Lori Wiggins, Extension 4-H Agent Taylor County - Northwest; Jerry Culen, Associate Professor Environmental Education, Department of Family Youth and Community Sciences, University of Florida

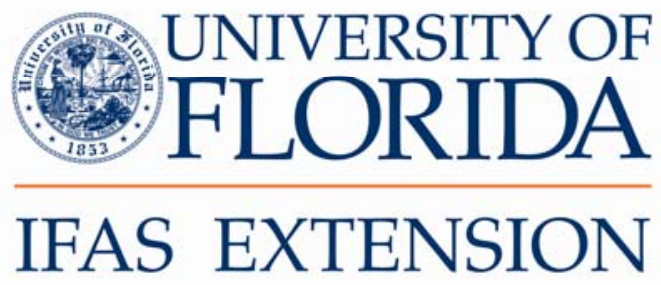

COOPERATIVE EXTENSION SERVICE, UNIVERSITY OF FLORIDA, INSTITUTE OF FOOD AND AGRICULTURAL SCIENCES, Larry R. Arrington, Director, in cooperation with the United States Department of Agriculture, publishes this information to further the purpose of the May 8 and June 30 , 1914 Acts of Congress; and is authorized to provide research, educational information and other services only to individuals and institutions that function with non-discrimination with respect to race, creed, color, religion, age, disability, sex, sexual orientation, marital status, national origin, political opinions or affiliations. The information in this publication is available in alternate formats. Single copies of extension publications (excluding 4-H and youth publications) are available free to Florida residents from county extension offices. Information on copies for out-of-state purchase is available from IFAS-Extension Bookstore, University of Florida, PO Box 110011, Gainesville, FL 32611-0011. Information about alternate formats is available from IFAS Communication Services, University of Florida, PO Box 110810, Gainesville, FL 32611-0810. This information was published June 2005 as 4-H FOM 14, Florida Cooperative Extension Service. Reviewed June 2005. 